\title{
Gondwana Vertebrate Faunas of India: Their Diversity and Intercontinental Relationships
}

\author{
${ }^{1}$ Geological Studies Unit, Indian Statistical Institute, 203 B. T. Road, Kolkata 700108, India; email: saswati@isical.ac.in \\ ${ }^{2}$ Department of Geology and Geophysics, Indian Institute of Technology, Kharagpur 721302, India; email: sray@gg.iitkgp.ac.in \\ *Corresponding author
}

(Received : 23/12/2018; Revised accepted : 11/09/2019)

https://doi.org/10.18814/epiiugs/2020/020028

The twelve Gondwanan stratigraphic horizons of India have yielded varied vertebrate fossils. The oldest fossil record is the Endothiodon-dominated multitaxic Kundaram fauna, which correlates the Kundaram Formation with several other coeval Late Permian horizons of South Africa, Zambia, Tanzania, Mozambique, Malawi, Madagascar and Brazil. The Permian-Triassic transition in India is marked by distinct taxonomic shift and faunal characteristics and represented by small-sized holdover fauna of the Early Triassic Panchet and Kamthi fauna. The Middle and Late Triassic saw extensive radiations of the indigenous and living faunas in the form of new temnospondyls, varied archosauromorphs, the basal dinosaurs, non-mammalian cynodonts and mammaliaforms. All the Triassic Gondwanan horizons of India can be correlated with other horizons around the world, resulting in precise biostratigraphic correlation. The Triassic-Jurassic transition in India show marked biotic turnover, which may have resulted from global warming and volcanism. On a Pangaean landscape, the Indian Gondwanan vertebrate assemblages reflect major transformations in vertebrate evolution, global faunal transitions, and constitute important biostratigraphic markers.

\section{Introduction}

The Late Palaeozoic terrestrial communities were dominated by the stem-amphibians (temnospondyls) and non-mammalian synapsids, whereas the diapsids remained a minor component (Padian and Sues, 2015). The best known groups were the aquatic mesosaurs, lizardlike millerosaurs, procolophonids and large pareiasaurs. Mesozoic is the time when the species richness started to increase globally as well as locally with the appearance of new genera and early radiation of many extant lineages, producing highly diverse terrestrial vertebrates in the vacant niches created throughout the world due to the endPermian extinction event. Diapsids diversified rapidly by the Middle Triassic in to many communities of continental tetrapods, whereas the non-mammalian synapsids became a minor components for the remainder of the Mesozoic Era. The Gondwana basins of peninsular India (Fig. 1A) aptly exemplify the diverse vertebrate faunas found from the Late Palaeozoic and Mesozoic. During the last few decades much emphasis was given on explorations and excavations of vertebrate fossils in these basins which have yielded many new fossil vertebrates, significant both in numbers and diversity of genera, and providing information on their taphonomy, taxonomy, phylogeny, evolutionary history, palaeobiology, palaeoecology and palaeobiogeography. There are at least twelve Gondwanan stratigraphic horizons (Fig. 1B), which have yielded varied vertebrate fossils. In the current work, we review these vertebrate fossils from two perspectives. We give a comprehensive account of these fossils, their occurrences and taxonomy, followed by their global correlation and biostratigraphic implications. The study highlights several waves of faunal replacements, especially at the Permian-Triassic and TriassicJurassic boundaries.

\section{Gondwana Basins of India}

The Gondwana deposits of India mark the resumption of sedimentation during the Permo-Carboniferous time after a long gap since the Proterozoic, and were deposited in glacial, fluvioglacial, fluviatile and lacustrine conditions. The age of these sediments ranges from the Late Carboniferous (ca. $290 \mathrm{Ma}$ ) to Middle Jurassic, as separation of the Indian plate from the Gondwana landmass was initiated during the onset of the Late Jurassic (ca. 167 Ma, Chatterjee et al., 2017). The Gondwana sediments accumulated in a number of isolated intracratonic basins of peninsular India bounded by faults developed along Precambrian lineaments during deposition. The basins subsided between normal faults, accommodating the Gondwana successions of 1-4 km in thickness (Veevers and Tewari, 1995). There are four major intracratonic basins - the Pranhita-Godavari (henceforth P-G Basin), Satpura, Son-Mahanadi and Damodar (Fig. 1A) - that document the thick Gondwana Supergroup, which may be subdivided into a Lower Gondwana Group characterized by the Palaeozoic 


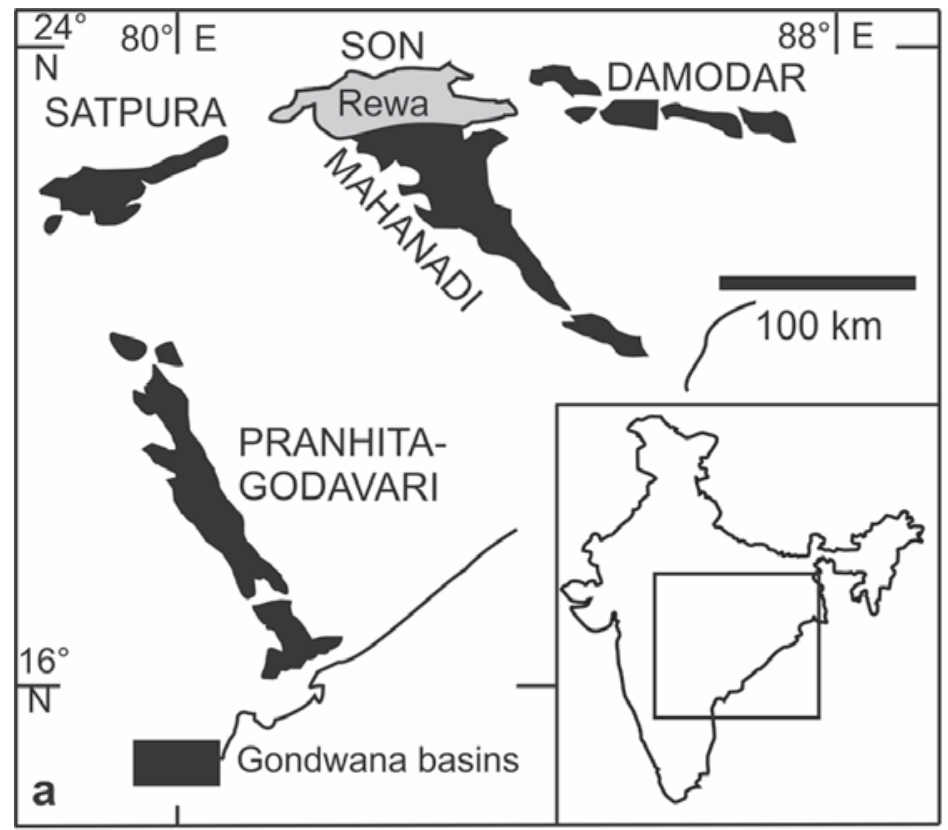

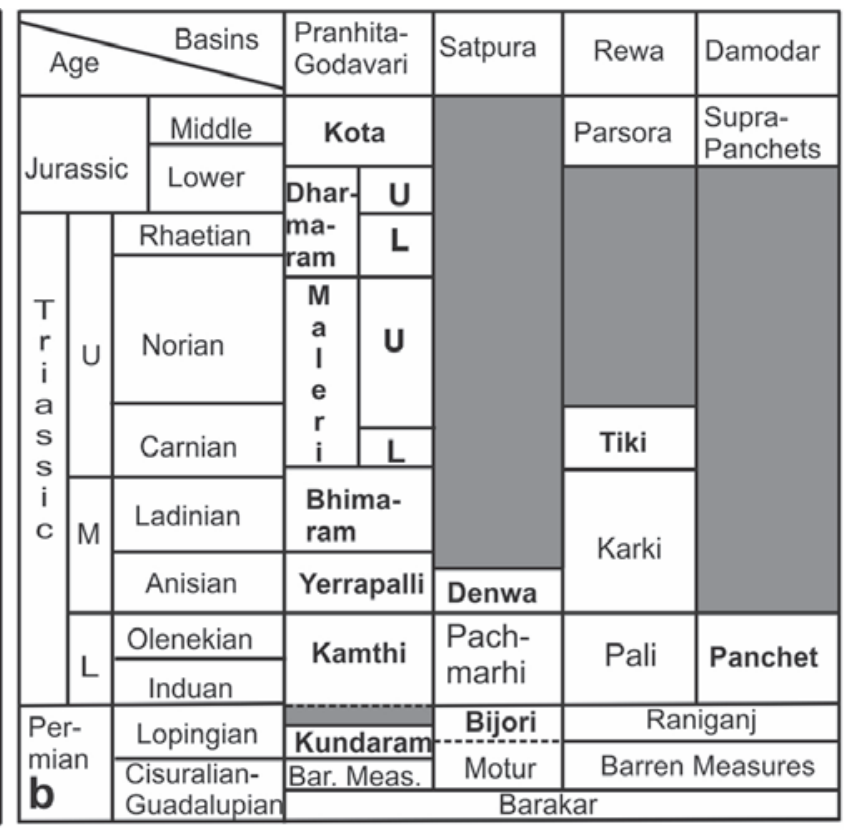

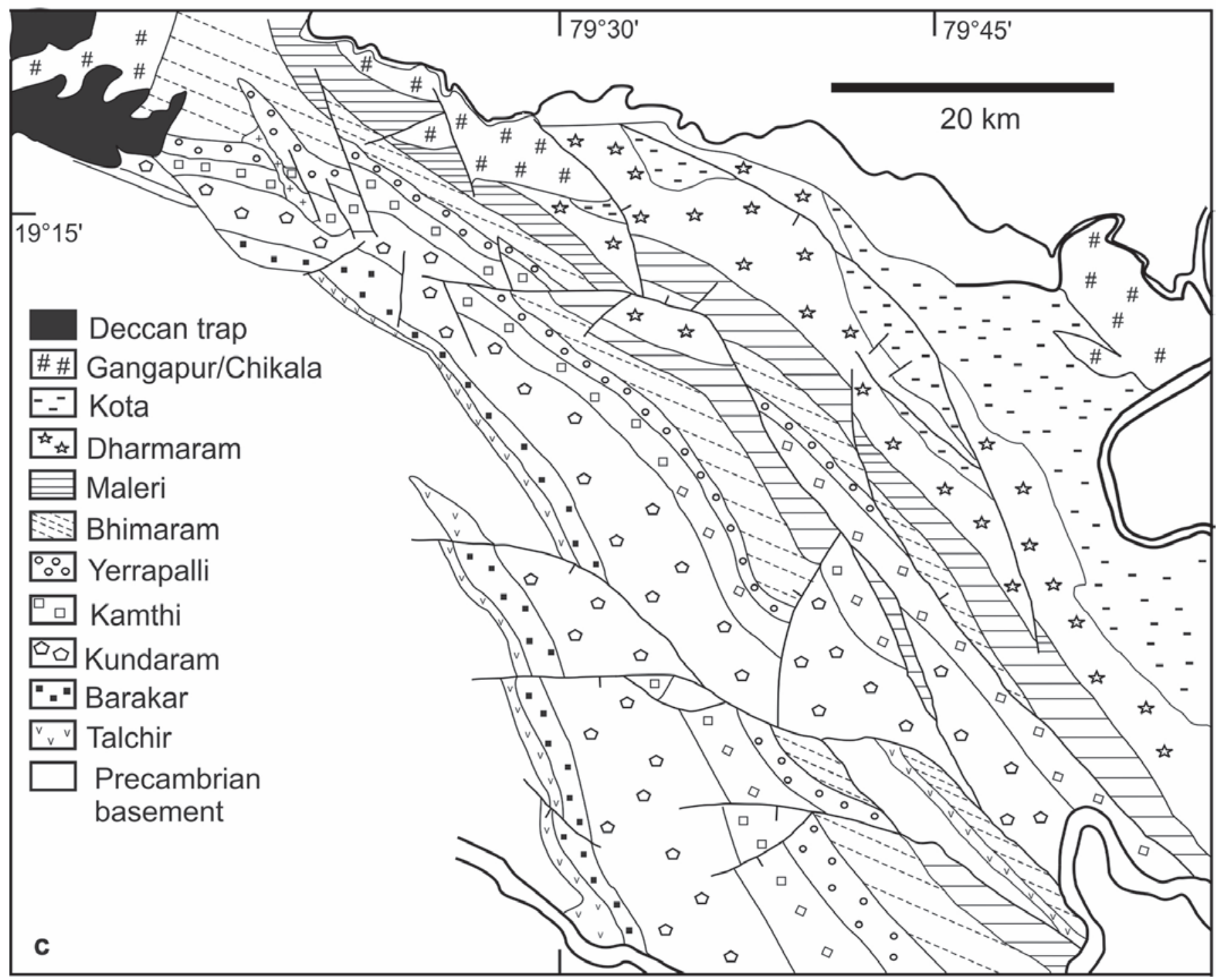

Figure 1 A, Gondwana basins of peninsular India (after Bandyopadhyay, 1999); B, Generalized Gondwana stratigraphy showing the fossilbearing horizons in bold (after Bandyopadhyay and Sengupta, 2006; Mukherjee et al., 2012; Ray 2015); C, Geological map of the PranhitaGodavari Basin (after Kutty et al., 1987; Ray, 1997). 
Glossopteris-Gangamopteris flora and an Upper Gondwana Group dominated by the Mesozoic Dicroidium-Lepidopteris-Ptilophyllum flora (Cotter and De, 1917; Robinson, 1970; Pascoe, 1975; Mukhopadhyay et al., 2010). The Lower Gondwana succession in most of the basins shows uniform lithological features, starting with the glacio-fluvial Talchir Formation and followed by the coal-bearing Barakar Formation (Fig. 1B). The Upper Gondwana succession of these basins, however, differs considerably and the formations are defined on the basis of distinctive lithology, fossil flora and fauna (Fig. 1B).

Among the four Gondwana basins of India (Fig. 1A), the Gondwana succession of the P-G Basin occurs in a narrow, rectilinear half-graben (400 km long and $75 \mathrm{~km}$ wide) trending NNW-SSE $\left(330^{\circ}\right.$ $150^{\circ}$ ) and bordered on both sides by the Precambrian rocks (Fig. 1C). The overall dip of this half-graben basin, which was formed with the hanging-wall block lying to its west (Biswas, 2003; Chakraborty et al., 2003), is $5^{\circ}-12^{\circ}$ towards NE (Chakraborty et al., 2003) and the general palaeocurrent direction is to the north (Sengupta, 1970). Seven vertebrate-bearing horizons have been identified from this basin, which have yielded highly diverse vertebrate remains (Bandyopadhyay, 1999). These include the Late Permian Kundaram Formation, and different Triassic horizons such as the Kamthi, Yerrapalli, Maleri and Lower Dharmaram formations, and the Jurassic Upper Dharmaram and Kota formations (Bandyopadhyay, 1999, 2011). The Maleri Formation has two vertebrate assemblages, which have led to a biochronological subdivision into lower (Carnian) and upper (Norian) horizons (Kutty and Sengupta 1989).

The westernmost Satpura basin (Fig. 2A) is rhomboidal in outline, and is about $200 \mathrm{~km}$ long and $60 \mathrm{~km}$ wide. The longer sides are marked
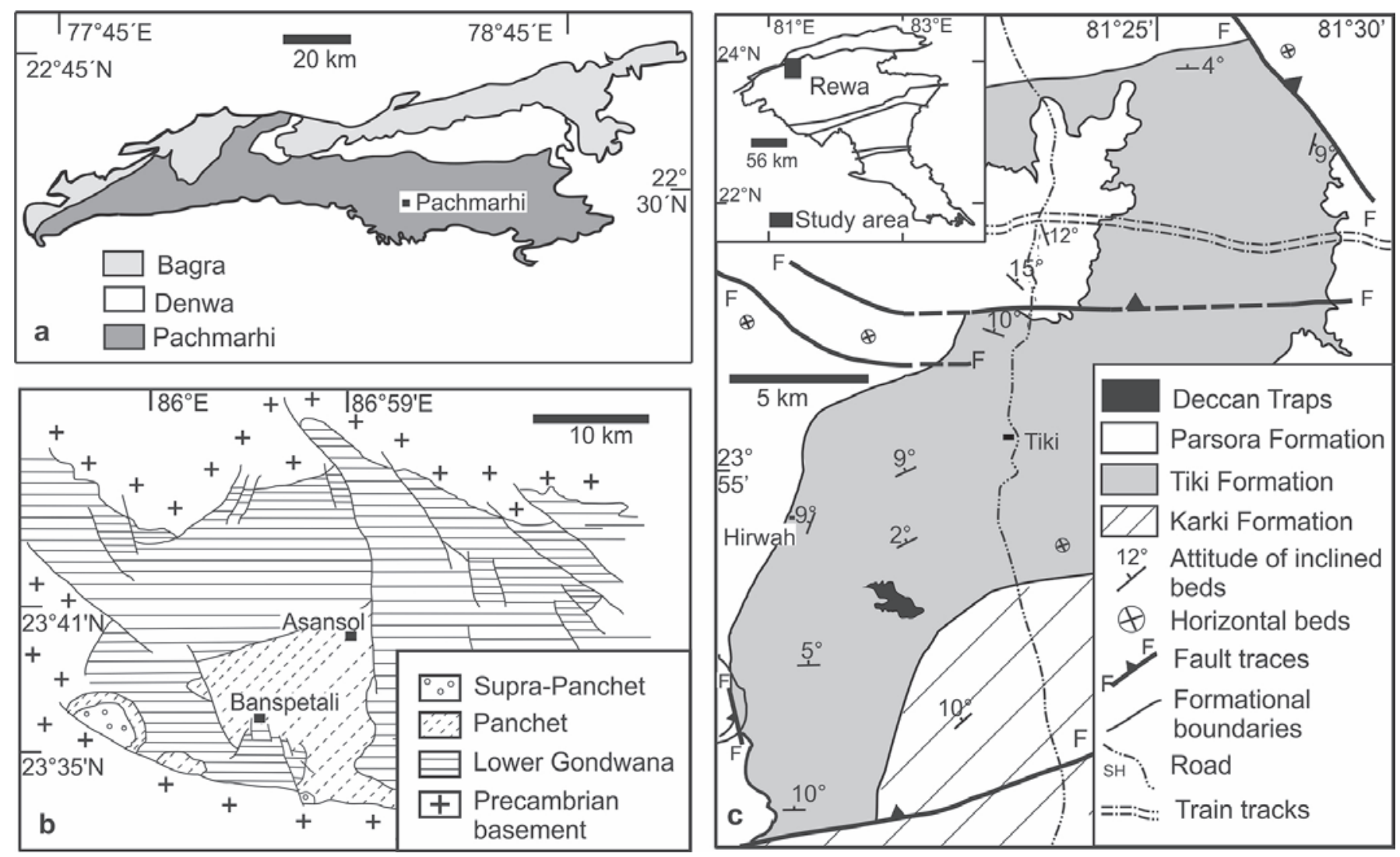

Figure 2. Geological maps of A, Satpura Basin (after Sengupta et al., 2016); B, Damodar Basin (after Ray, 2005); C, Rewa Basin (after Mukherjee et al., 2012). by the ENE-WSW-trending Son-Narmada (south) and Tapti (north) faults. This basin is a pull-apart basin and developed due to the extension related to strike-slip movements along these two faults (Chakraborty et al., 2003). The regional strike of the basin fill is ENEGondwana succession (ca. $4 \mathrm{~km}$ in thickness) consists of siliciclastic sediments and ranges in age from Early Carboniferous to the Middle Triassic (Crookshank, 1936; Pascoe, 1975; Robinson, 1970; Bandyopadhyay and Sengupta, 1999). There are only two vertebratebearing horizons in this basin: the Late Permian Bijori Formation and the Middle Triassic Denwa Formation (Lydekker, 1885a, b; Bandyopadhyay and Sengupta, 1999).

In eastern India along the E-W trending Damodar Basin (Fig. 1A), several isolated basins occur, which are of similar morphology and structural characteristics. These are the Karanpura and Bokaro basins along with the small outliers of Auranga and Hutar, Jharia Basin and Raniganj Basin from west to east. The basins are all rhombic, fault-bound with numerous intrabasinal faults at high angles to the bounding faults along their longer sides (Chakraborty et al., 2003). Of these basins, the Raniganj Basin is a fault-controlled subsidence basin which has produced vertebrate remains. It is rhomboidal in outline (70 km long and $20 \mathrm{~km}$ wide), relatively long in WNW-ESE direction with low $\left(5^{\circ}-7^{\circ}\right)$ dip towards south (Fig. 2B). The Damodar Basin has a thick succession (ca. $3 \mathrm{~km}$ thick) of fluvioglacial, fluvial and lacustrine sediments, though vertebrate fossils are known from only one horizon, the Early Triassic Panchet Formation (Fig. 1B, 2B).

The Son-Mahanadi, centrally positioned in peninsular India (Fig. $1 \mathrm{~A})$, is a composite basin and comprises three sub-basins, namely WSW and the regional formation dip is ca. $5^{\circ}$ to the north. The 
the Rewa Basin in the north (Fig. 2C, inset), the centrally-located Hasdo-Arand Basin, and the Mahanadi Basin in the south. The Rewa Basin is bounded by the Malwa ridge in the north and by the Manendragarh-Pratapur ridge in the south (Chakraborty et al., 2003). The basin is rhomboidal in outline and extends in an essentially ENEWSW direction (400 km x $150 \mathrm{~km}$ ). The overall attitude of the basinfill strata is less than $15^{\circ}$ to the north. This basin is considered a fault-controlled subsidence basin (Chakraborty et al., 2003), and is characterized by a thick and continuous Triassic succession (Mukherjee et al., 2012). The Triassic succession is subdivided into the Pali Formation at the base, followed successively by an arenaceous Karki Formation and a mud-dominated Tiki Formation (Mukherjee et al., 2012; Fig. 1B). Of these, the Tiki Formation (Fig. 2C) has yielded a rich Late Triassic vertebrate fauna (Datta and Das, 1996; Datta, 2004, 2005; Prasad et al., 2008; Ray et al., 2016; Bhat et al., 2018a, b; Datta et al., 2019).

\section{Gondwana Vertebrate Faunas}

\section{Permian Vertebrate Fauna}

\section{Faunal characteristics}

In India, Permian vertebrates have a poor representation and are known from two distinct horizons, namely the Vihi (Gangamopteris) beds of the Mamal Formation of Kashmir (Bandyopadhyay, 1999) and the Kundaram Formation of the P-G Basin (Kutty, 1972; Ray, 1999, 2001). The Kashmir fauna is characterized by several palaeoniscoid fishes and archegosauroid temnospondyls (Woodward, 1905; Tripathi, 1962), the details of which were given by Bandyopadhyay (1999). Since there has been no update on the already available information, the faunal details are not repeated here.

On the other hand, the Kundaram Formation of P-G Basin has yielded a Late Permian multitaxic tetrapod fauna where the dominant component is the dicynodonts. The non-dicynodont members include a small captorhinid reptile (Kutty, 1972) and a medium-sized gorgonopsian (Ray and Bandyopadhyay, 2003). The dicynodont assemblage includes two species of the genus Endothiodon (E. mahalanobisi and E. uniseries), Dicynodontoides (= 'Kingoria'), Pristerodon, Oudenodon and Sauroscaptor (Fig.3A-B; Ray, 2000, 2001; Ray and Bandyopadhyay, 2003; Kammerer et al., 2016). The fauna is mostly represented by complete and partial skulls and lower jaws, and shows a preponderance of Endothiodon known from about 30 individuals (Ray, 1999; Ray and Bandyopadhyay, 2003). This skullonly accumulation, encrusted with thick iron-rich matrix and collected from overbank fines, is a lag deposit and has been attributed to prolonged subaerial exposure prior to burial, resulting in disarticulation and winnowing out of the postcrania by water flow as the heavier skulls resisted transportation and were subsequently buried near the site of death (Ray and Bandyopadhyay, 2003).

\section{Intercontinental relationships}

The Late Permian palaeogeography encompassed three large continental masses that are principally distributed at the mid-latitudes, namely the Gondwana, Laurasia and Siberia, joined together to form the supercontinent Pangaea (Bernardi et al., 2017). Well documented Late Permian tetrapod ecosystems are known from these landmasses, where the tetrapod associations were structured and provincialized at

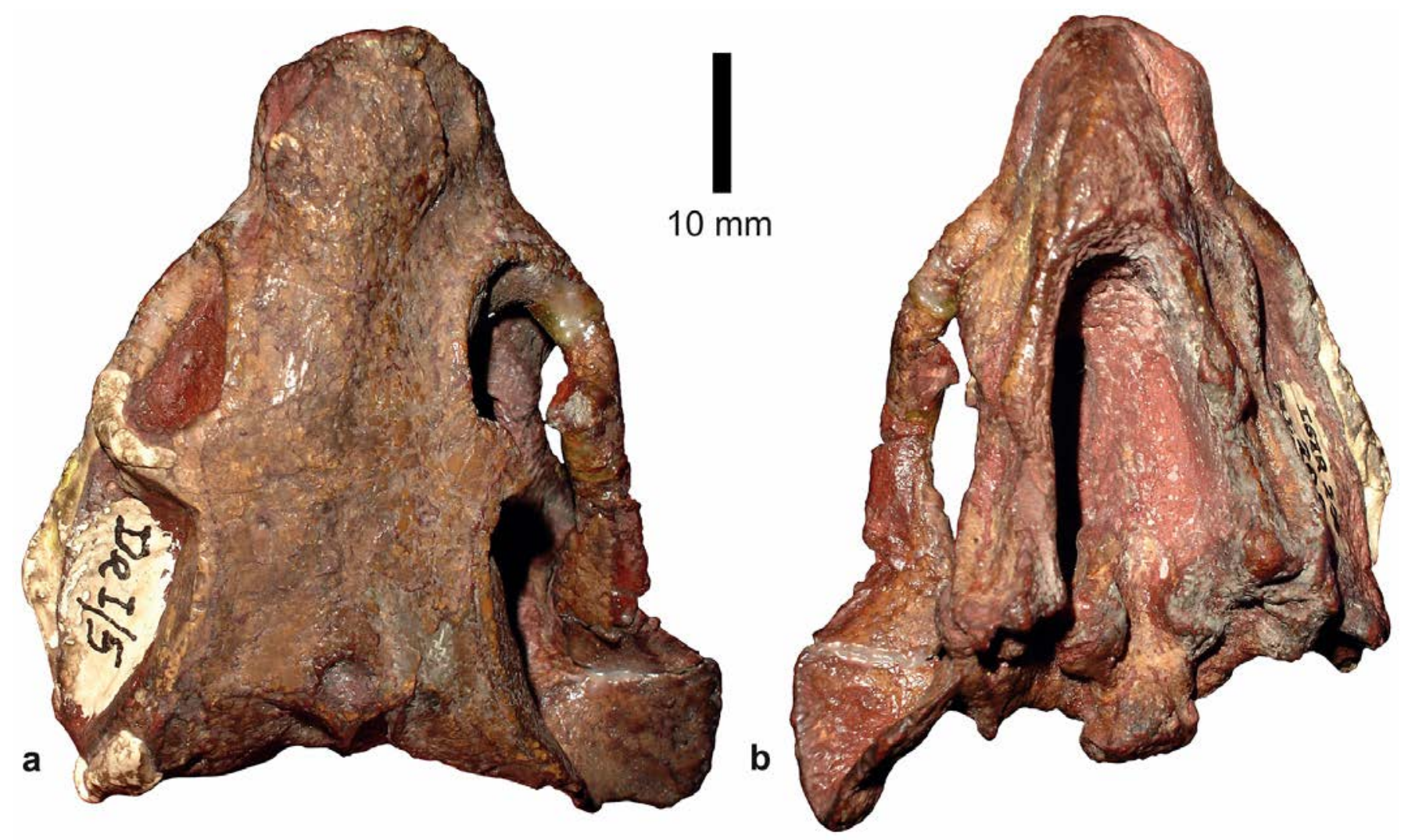

Figure 3. A-B, Sauroscaptor tharavati Kammerer et al. (2016). Skull of a small dicynodont from the Kundaram Formation of India in A, dorsal and $B$, ventral views. 
high taxonomic levels (Bernardi et al., 2017). Of these, the PermoTriassic Beaufort Group of the Karoo Basin in South Africa documents a rich tetrapod fossil record, which has resulted in its biostratigraphic subdivisions (Rubidge, 1995; Smith et al., 2012) with global applicability. Of the six Assemblage Zones (AZ) Pristerodon and Endothiodon appeared first in the Pristerognathus AZ, proliferated in the Tropidostoma AZ and persisted as a rare member in the Cistecephalus AZ (Rubidge, 1995). In addition, the Pristerognathus AZ contains the small dicynodont Diictodon, which constitutes about $85 \%$ of the total fossils found. It decreases to about $40 \%$ in the Tropidostoma AZ (Rubidge, 1995), where Rhachiocephalus and Endothiodon (E. miseries, E. bathystoma) constitute 10-30\% and $5 \%$, respectively. Similarly, the fossil fauna of the Cistecephalus AZ is composed of Diictodon (50\%) followed by Oudenodon (20\%), Cistecephalus (10\%), Pristerodon (5\%), Emydops (5\%), Aulacephalodon (5\%), Rhachiocephalus and Endothiodon (less than 2\%, Rubidge, 1995).

There are several other Endothiodon-bearing horizons in Africa, which are analogous to the Karoo environment and are found in Zimbabwe, Mozambique, Malawi, Zambia and Tanzania (King, 1992). In Zambia, the Lopingian is represented by the Upper Madumabisa Mudstone Formation in the Luangwa Basin, from which a single assemblage of 14 dicynodont taxa is known and correlated with the Cistecephalus AZ of South Africa (King, 1992; Angielcyzk et al., 2014; Sidor et al., 2014). The Late Permian tetrapod fossils are preserved in the Ruhuhu and Usili formations of the Ruhuhu Basin of Tanzania, where the tetrapods occur at multiple stratigraphic horizons in each formation (Angielczyk et al., 2014). The Usili horizons and the uppermost Ruhuhu horizon contain a single faunal assemblage dominated by dicynodonts consisting of endothiodonts, emydopoids, cryptodonts, and dicynodontoids (52\%), followed by gorgonopsians, therocephalians, cynodonts and notably abundant biarmosuchians (35\%), pareiasaurs (5.5\%) and temnospondyls (6.6\%). Bernardi et al. (2017) suggested that these horizons may be correlated with the upper Cistecephalus and/or lower Daptocephalus AZs of the Karoo Basin.

Endothiodon is also known from the K5 horizon of the Metangula
Graben, Mozambique along with an endemic kingoriid dicynodont Niassodon and a probable Oudenodon (Castanhinha et al., 2013). Based on the presence of Endothiodon and Oudenodon, the latter making its first appearance in the Tropidostoma AZ of South Africa, K5 is correlated broadly with the Tropidostoma and Cistecephalus AZs (Castanhinha et al., 2013). In addition, Endothiodon-bearing strata are also known from the Chiweta beds of Malawi (Frobisch, 2009; Bernardi et al., 2017). The Lower Sakamena Formation of Madagascar is known for its richness in the Late Permian fossils, which are characterized by the diapsids (Smith, 2000). Mazin and King (1991) described a dicynodont taxon, Oudenodon sakamenenis from the upper part of Lower Sakamena Formation. Though longranging, this genus is common in the Cistecephalus and Dicynodon AZs of South Africa suggesting a probable correlation.

Apart from Africa and India, a rich Late Permian fauna is known from the Rio do Rasto Formation of the Paraná Basin, Brazil (Cisneros and Abdala, 2005; Benardi et al., 2017). The Rio do Rasto Formation of the Paraná Basin has produced three local faunas containing vertebrates- the Aceguá, Posto Queimado and Serra do Cadeado (Barberena et al., 1991). Of these, the Serra do Cadeado local fauna consists of Endothiodon (Barberena et al., 1975) and long-snouted rhinesuchids, including Australerpeton cosgriffi, suggesting that the Serra do Cadeado fauna can be loosely correlated with Pristerognathus, Tropidostoma and Cistecephalus AZs.

A close similarity of the Kundaram vertebrate fauna with that of the Tropidostoma and/or Cistecephalus (AZ) was noted based on their dicynodont-content (Ray, 1999). Subsequent works by several authors have shown that Endothiodon dominates in the Kundaram fauna; the latter containing the long-ranging Pristerodon, Oudenodon and a cistecephalid Sauroscaptor (Ray, 2001; Kammerer et al., 2016), with a gorgonopsian (Ray and Bandyopadhyay, 2003) and a captorhinid (Kutty, 1972). Based on this dicynodont-rich fossil content, the Kundaram Formation may be correlated with the Tropidostoma and lower Cistecephalus AZs of South Africa, and several other Endothiodon-bearing African strata (Fig. 4). These include the upper Madumabisa Mudstones of Zambia, Ruhuhu and Kawinga formations of Tanzania, K5 horizon of Mozambique, Chiweta Bed of Malawi. In

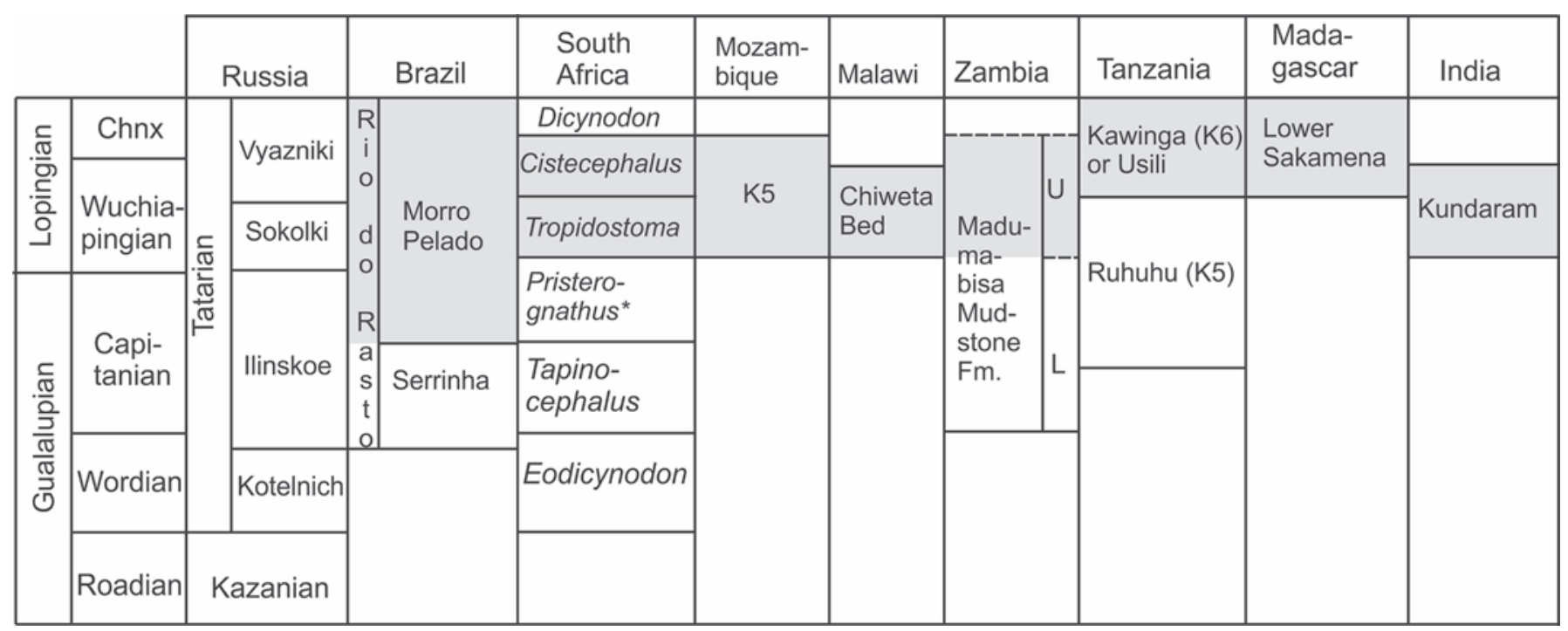

Figure 4. Correlation of the Upper Permian vertebrate-bearing horizons around the world (shaded in grey). Middle-Upper Permian time scale follows Gradstein et al. (2012). Abbreviation: Chnx, Changhsingian; Sources of information: Rubidge (1995), Ray (1999), Cisneros and Abdala (2005), Smith et al. (2012), Bernardi et al. (2017). 
addition, the Kundaram Formation may be correlated with the Lower Sakamena Formation of Madagascar and the Morro Pelado member of the Rio do Rasto Formation of Brazil. Hence, an early Lopingian (Wuchiapingian) age is suggested for the Kundaram vertebrate fauna.

\section{Triassic Vertebrate Faunas}

The largest and most devastating mass extinction event took place at the end of the Permian period when $70 \%$ of marine genera and 70 $80 \%$ of the terrestrial families became extinct (Dineen et al., 2014). The Triassic period (252.2-201.3 my; Gradstein et al., 2012) is characterized by extraordinary changes in terms of vegetation due to different climatic conditions, two major extinction events and advancement in vertebrate evolution (Sues and Fraser, 2010). The typical hot and arid climate of the Late Permian continued at the beginning of the Triassic but gradually the period witnessed fairly moist and hot climate of monsoon type with an alternation of wet and dry seasons (Robinson, 1970; Preto et al., 2010; Sues and Fraser, 2010). The long 50 million year Triassic period started with impoverished terrestrial vertebrate diversity when the competition for niche space was low because of low beta-diversity which gradually increased with subsequent origination, speciation and interaction between species resulting in diversification (Hoffmann et al., 2013; Hautmann, 2014). The geologically ephemeral Early Triassic fauna was replaced by a novel Middle Triassic community with renewed incumbency (Roopnarine, 2018) but low level of cosmopolitanism (Sahney and Benton, 2008). The period ended with a highly diverse vertebrate fauna that included varied temnospondyls, lepidosaurs, crocodilians, non-avian dinosaurs and early mammals, thus restoring the terrestrial tetrapod community and setting the stage for the modern terrestrial ecosystem (Fraser, 2006; Sues and Fraser, 2010). The Late Triassic thus may be considered as a transitional period between ancient and modern terrestrial ecosystems.

Three general continental tetrapod faunas dominated the Triassic. These faunas comprised the 'Palaeozoic holdovers', which was the Early Triassic tetrapod assemblage that survived the end-Permian extinction to proliferate during the Triassic, the 'indigenous' Triassic fauna, which appeared and became extinct during the Late Triassic, and the 'living' fauna, which appeared during the Late Triassic and are still continuing today. This latter group consists of the dinosaurs (including birds), crocodylians, turtles, lepidosaurs and several extant groups of amphibians (Romer, 1966; Padian and Sues, 2015). Representative fossils of these groups are found in the Indian scenario, the details of which are discussed in the following section.

\section{Early Triassic}

There are two Early Triassic horizons bearing representative vertebrate fossils in India. These include the Panchet Formation of the Damodar basin and the Kamthi Formation of the P-G Basin (Fig. 1B). Of these, the Panchet Formation (Fig. 2B), comprising essentially siliciclastic sediments, has yielded various vertebrate remains in the sandstone and shale. The ichthyofaunal assemblage includes numerous scales, teeth and tooth plates of actinopterygians, dipnoans and chondrichthyans suggesting lack of endemism (Gupta, 2009). This formation also includes several temnospondyls, dicynodonts, diapsids and cynodonts (Table 1). The temnospondyls are represented by the trematosaurids Indolyrocephalus, Gonioglyptus, a rhytidosteid Indobrachyops, a lydekkerinid, Lydekkerina, a lapillopsid Manubrantlia, a plagiosaurid Capulomala, a brachyopid Pachygonia, a probable tupilakosaurid Tupilakosaurus sp., and an indeterminate benthosuchid (Bandyopadhyay, 1999, 2011; Warren et al., 2009; D. P. Sengupta, pers comm.). The Panchet fauna also includes possibly three species of the dicynodont, Lystrosaurus (Tripathi and Satsangi, 1963; Ray, 2005; Gupta and Das, 2011), two cynodonts, Thrinxodon and Panchetocynodon (Satsangi, 1987; Das and Gupta, 2012) and the diapsid Proterosuchus (Huxley, 1865; Bandyopadhyay, 1999, 2011; Table 1).

The other Early Triassic vertebrate-bearing horizon is the Kamthi Formation of the P-G Basin. This formation has purple siltstone and ferruginous sandstones, which are pebbly in places. The Kamthi siltstone has yielded numerous small, articulated but poorly preserved, skeletons (Fig. 5A-B), which were identified as a dicynodont (Bandyopadhyay and Sengupta, 2006). Although the skulls are mostly broken or distorted, these are large with flaring posterior ends, especially the squamosals. The postcranial skeletons are, in comparison well preserved and articulated. The Kamthi dicynodont is characterized by a robust humerus with expanded ends, which is smaller than the associated femur, and the presence of two U-shaped deep notches on the dorsal margin of the iliac blade (Fig. 5B). Such notched iliac border resulting in three possible origination sites for the ilio-femoralis muscle is seen only in the dicynodont Lystrosaurus (Ray, 2006). Presence of this unique feature suggests that the Kamthi dicynodont was Lystrosaurus, though other vertebrate fossils are yet
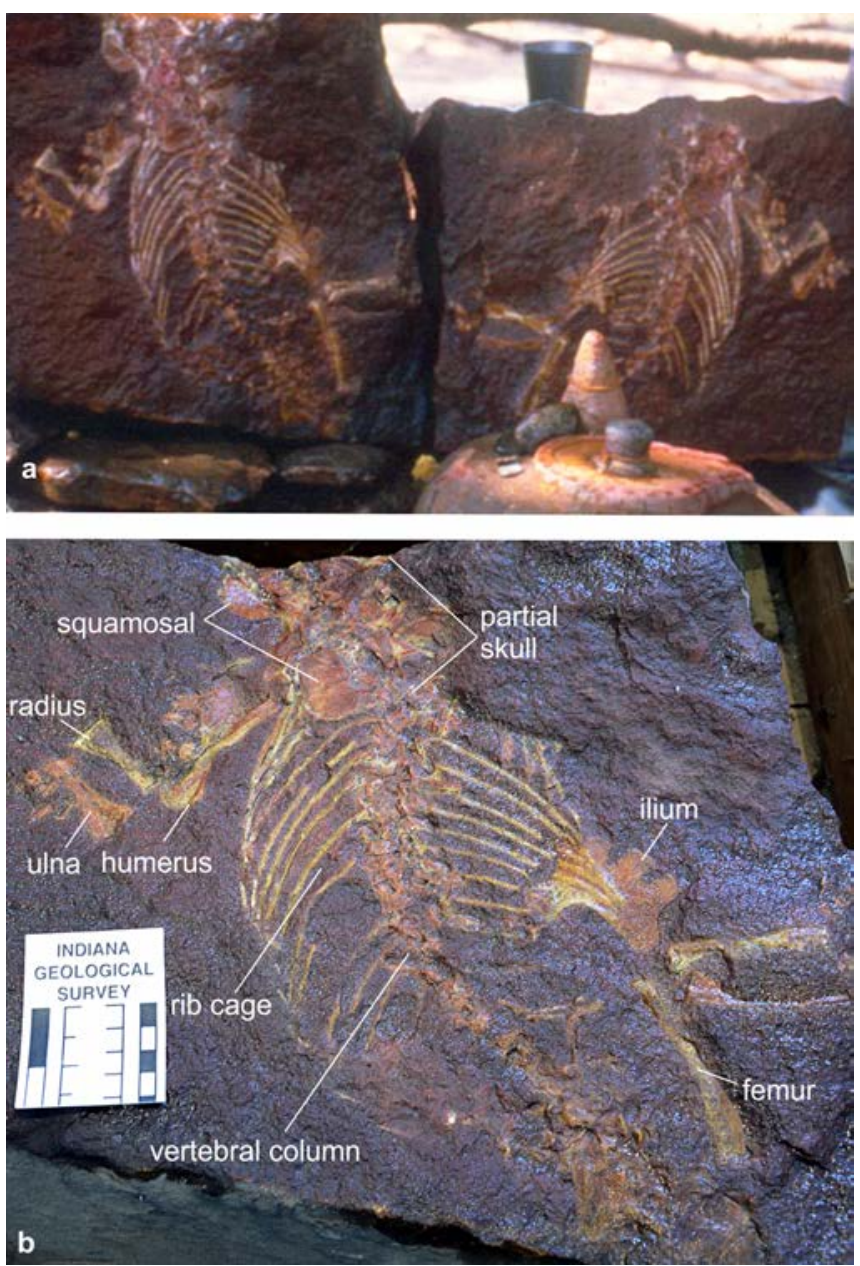

Figure 5A-B, Lystrosaurus sp. Articulated skeletons found on the purple siltstone of the Kamthi Formation. 
Table 1. Lower and Middle Triassic vertebrate faunas of India. Sources of information: Tripathi and Satsangi (1963), Bandyopadhyay (2011), Ray (2005), Bandyopadhyay and Sengupta (2006), Gupta and Das (2011), Das and Gupta (2012), Sengupta et al. (2017), D. P. Sengupta pers.comm. (2018)

\begin{tabular}{|c|c|c|c|}
\hline & Panchet & Yerrapalli & Denwa \\
\hline \multicolumn{4}{|l|}{ PISCES } \\
\hline Acrolepidae & Indeterminate genus & - & - \\
\hline Perleididae & Indeterminate genus & - & - \\
\hline Chondrichthyes & Indeterminate genus & - & - \\
\hline Ceratodontidae & Indeterminate genus & Ceratodus sp. & Ceratodus sp. \\
\hline Saurichthyformes & - & Saurichthys sp. & \\
\hline \multicolumn{4}{|l|}{ AMPHIBIA } \\
\hline Rhytidosteidae & Indobrachyops panchetensis & - & - \\
\hline \multirow[t]{3}{*}{ Trematosauridae } & Indolyrocephalus huxleyi & - & Lonchorhynchine indet. \\
\hline & Gonioglyptus fragilis & & \\
\hline & Gonioglyptus longirostris & & \\
\hline Lapillopsidae & Manubrantlia khaki & - & - \\
\hline Lydekkerinidae & Lydekkerina huxleyi & & \\
\hline Plagiosauridae & Capulomala panchetensis & - & \\
\hline Brachyopidae & ?Pachygonia incurvata & - & Undescribed \\
\hline Benthosuchidae & ?benthosuchid & - & - \\
\hline Tupilakosauridae & Tupilakosaurus sp. & - & - \\
\hline Mastodonosauridae & - & Parotosuchus rajareddyi & - \\
\hline Capitosauroidea & - & - & $\begin{array}{l}\text { Paracyclotosaurus } \\
\text { crookshanki } \\
\text { Cherninia denwai }\end{array}$ \\
\hline \multicolumn{4}{|l|}{ DIAPSIDA } \\
\hline Proterosuchidae & $\begin{array}{l}\text { Proterosuchus } \\
\text { (Chasmatosaurus, } \\
\text { Ankistrodon) indicus }\end{array}$ & - & - \\
\hline Rhynchosauridae & - & Mesodapedon kuttyi & Undescribed \\
\hline Allokotosauria & - & Pamelaria dolichotrachlea & Shringasaurus indicus \\
\hline Erythrosuchidae & - & Erythrosuchus sp. & \\
\hline Aphanosauria & - & Yarasuchus deccanensis & - \\
\hline \multicolumn{4}{|l|}{ SYNAPSIDA } \\
\hline Lystrosauridae & $\begin{array}{l}\text { Lystrosaurus murrayi } \\
\text { L. cf. declivis, L. cf. curvatus }\end{array}$ & $\begin{array}{l}- \\
-\end{array}$ & - \\
\hline Kannemeyeriiform & - & Wadiasaurus indicus & Undescribed taxa \\
\hline Stahleckeriidae & - & Rechnisaurus cristarhynchus & - \\
\hline Thrinaxodontidae & Thrinaxodon bengalensis & - & - \\
\hline Brasilodontidae & $\begin{array}{l}\text { Panchetocynodon } \\
\text { damodarensis }\end{array}$ & - & - \\
\hline Trirachodontidae & - & Trirachodontidae indet. & - \\
\hline
\end{tabular}

to be recovered from the formation. In addition, the temnospondyl Brachyops laticeps is known from the upper part of the Kamthi Formation or the 'Mangli” beds' (Owen, 1855).

\section{Middle Triassic}

The Yerrapalli Formation of the P-G Basin and the Denwa Formation of the Satpura Basin (Figs 1B-C, 2A) are the major Middle Triassic vertebrate-bearing horizons of India (Crookshank, 1936; Jain et al., 1964), though fragmentary remains of a dicynodont and temnospondyl are known from the Bhimaram Formation (Kutty et al., 1987). The strata of the Yerrapalli Formation comprise red to violet mudstone alternating with quartzose sandstone, with mudstone being fossil-rich. The vertebrate assemblage (Table 1) consists of the ceratodontid Ceratodus, the saurichthyform Saurichthys, the capitosaur Parotosuchus, the stenaulorhynchine rhynchosaur Mesodapedon, the allokotosaur Pamelaria, the erythrosuchid Erythrosuchus, the aphanosaur Yarasuchus, two kannemeyeriiform dicynodonts (Wadiasaurus and Rechnisaurus), and a trirachodontid.

The Denwa Formation of the Satpura Basin is the other wellknown Middle Triassic vertebrate-bearing horizon of India. On the basis of lithology, Maulik et al. (2000) divided the formation into lower and upper parts. The lower Denwa comprises multistoried, sheet-like medium-fine grained sandstone bodies interleaved with red 
mudstones, while the upper Denwa is a mudstone-dominated unit characterized by layers of ribbon-shaped channel-fill bodies and sandy to heterolithic sheet sandstones encased within the mudstones. The vertebrate assemblage (Table 1) includes the ceratodontid Ceratodus, the capitosaurs Paracyclotosaurus, Cherninia, and three indeterminate taxa, the undescribed brachyopid, the lonchorhynchine trematosaurid, an undescribed rhynchosaur, and various medium-large dicynodonts (Mukherjee and Sengupta, 1998; Bandyopadhyay and Sengupta, 1999; Mukherjee et al., 2019). Recently the horned allokotosaur Shringasaurus (Fig. 6A-B) has been described from this horizon (Sengupta et al., 2017). This is the only known horned Triassic reptile to date.

\section{Late Triassic}

Three Late Triassic horizons of India contain distinct vertebrate assemblages - the Maleri and the lower Dharmaram formations of the P-G Basin (Table 2) and the Tiki Formation of the Rewa Basin (Table 3). The Maleri Formation is represented by a mudstonedominated, nearly 400-m-thick fluvial succession deposited under a semi-arid climate (Sarkar, 1988) and may be subdivided into two parts. The lower part (100-150 m thick) comprises vertically stacked siltstone-dominated intervals, whereas the upper part (200-300 m thick) contains multistoried, sheet sandstone, vertically separated by comparatively thicker siltstone-dominated intervals (Dasgupta and Ghosh, 2018). Numerous thin, sheet-like and lensoid bodies of crossbedded grainstones occur at different stratigraphic levels (Dasgupta et al., 2017).

This formation has yielded two distinct vertebrate assemblages
(Kutty and Sengupta, 1989; Prasad et al., 2008; Bandyopadhyay, 2011; Chakravorti and Sengupta, 2019). The Maleri Formation encompasses 12 families, which represent 25 genera and species (Table 2), of which 12 and 13 taxa belonged to the lower and upper Maleri faunas, respectively. The lower Maleri fauna is characterized by an association of the phytosaur Parasuchus, the rhynchosaur Hyperodapedon and the metoposaurid Panthasaurus (Chatterjee, 1974, 1978; RoyChowdhury, 1965; Chakravorti and Sengupta, 2019). Other vertebrates comprise a ptychoceratodontid, a xenacanthid, a prolacertid (?), a yet to be described phytosaur similar to Angistorhinus, an aetosaur similar to Typothorax, an allokotosaur, a basal saurischian, and two cynodont genera (Bandyopadhyay, 2011; Novas et al., 2011; Nesbitt et al., 2017; Table 2).

The upper Maleri fauna, on the other hand, includes two chigutisaurids, Kuttycephalus and Compsocerops (Kutty and Sengupta, 1989), two derived phytosaurs similar to Angistorhinus and Leptosuchus (Hungerbühler et al., 2002), two dinosauromorphs (Novas et al., 2011), and a dicynodont very similar to Stahleckeria (Novas et al 2011; Bandyopadhyay, 2011; Table 2). This faunal assemblage occurs in a stratigraphically younger horizon, from which Panthasaurus, Hyperodapedon, Parasuchus and Exaeretodon had disappeared, suggesting that the latter is younger than the lower Maleri fauna (Kutty and Sengupta, 1989).

The Maleri Formation is overlain by the Dharmaram Formation, one of the most important stratigraphic horizons, and encompasses the Triassic-Jurassic boundary in the Indian Gondwana (Bandyopadhyay and RoyChowdhury, 1996). It has been biochronologically divided into a lower part bearing a Rhaetian fauna and an upper part yielding a Hettangian fauna (Bandyopadhyay and

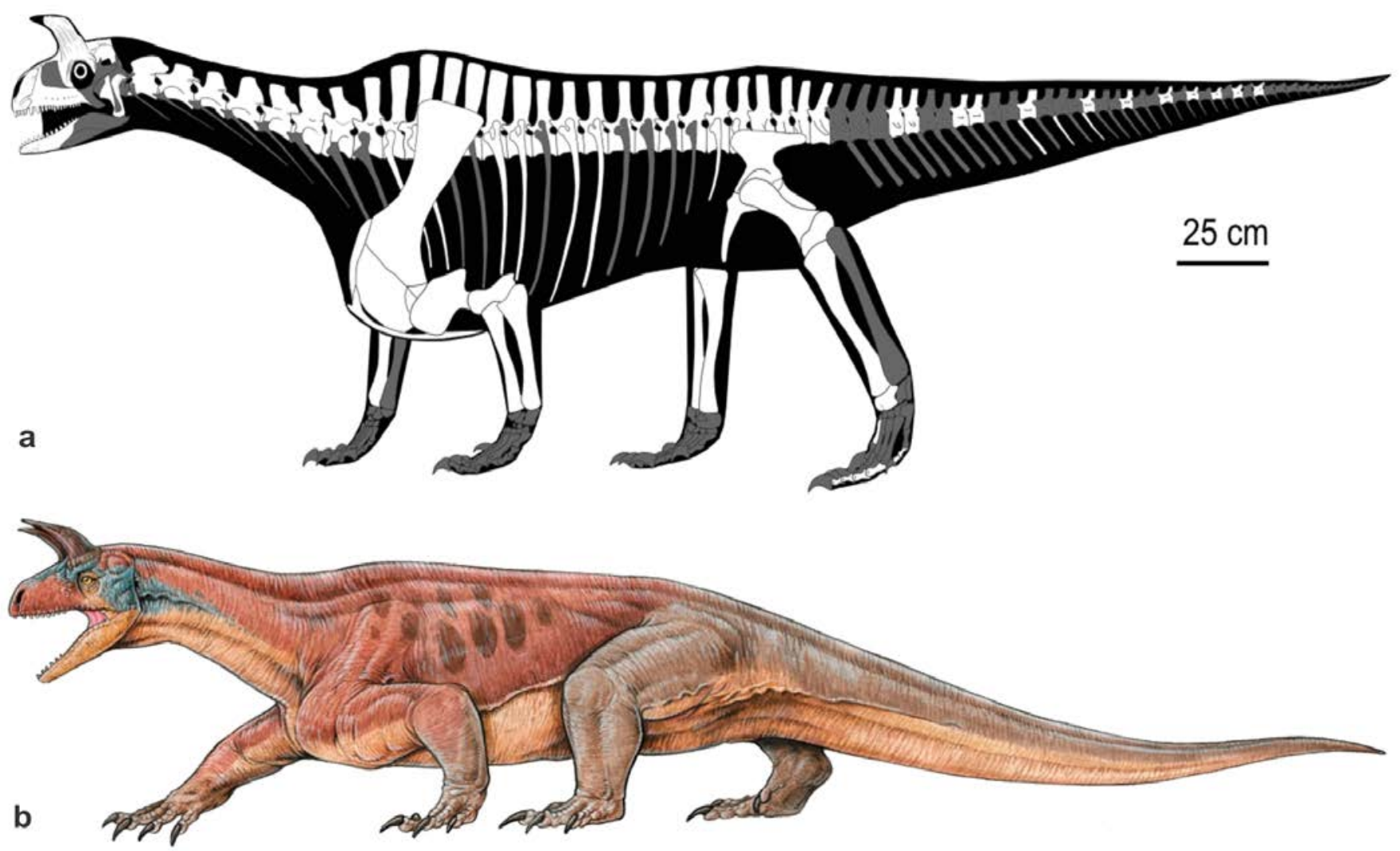

Figure 6. A-B, Shringasaurus indicus Sengupta et al. (2017). A horned allokotosaur from the Denwa Formation of India as A, reconstructed skeleton; B, restored life form. Missing bones are shaded by grey. 
Table 2. Late Triassic vertebrates from different stratigraphic horizons of the P-G Basin, India. Sources of information: Kutty and Sengupta (1989), Bandyopadhyay (1999, 2011), Prasad et al. (2008), Chakravorti and Sengupta (2019)

\begin{tabular}{|c|c|c|c|}
\hline & Lower Maleri & Upper Maleri & Lower Dharmaram \\
\hline \multicolumn{4}{|l|}{ PISCES } \\
\hline \multirow[t]{2}{*}{ Ceratodontidae } & Ptychoceratodus virapa & - & - \\
\hline & - & P. nageswari & P. nageswari \\
\hline Polyacrodontidae & Polyacrodus? contrarius & - & - \\
\hline Xenacanthidae & Mooreodontus indicus & M. indicus & M. indicus \\
\hline \multicolumn{4}{|l|}{ AMPHIBIA } \\
\hline Metoposauridae & Panthasaurus maleriensis & - & - \\
\hline \multirow[t]{2}{*}{ Chigutisauridae } & - & Compsocerops cosgriffi & - \\
\hline & - & Kuttycephalus triangularis & - \\
\hline \multicolumn{4}{|l|}{ DIAPSIDA } \\
\hline \multirow[t]{2}{*}{ Phytosauria } & Parasuchus hislopi & cf. Leptosuchus & Nicrosaurus-like form \\
\hline & Angistorhinus & Angistorhinus & - \\
\hline Rhynchosauria & Hyperodapedon huxleyi & - & - \\
\hline Prolacertiformes & Malerisaurus robinsonae & - & - \\
\hline \multirow[t]{2}{*}{ Aetosauria } & cf. Typothorax & Aetosauria indet. & Paratypothorax-like form \\
\hline & - & - & Desmatosuchus-like form \\
\hline \multirow[t]{5}{*}{ Dinosauriformes } & Alwalkeria maleriensis & Gen indet. A (ISI R282) & J. asymmetrica \\
\hline & & Gen indet. A (284) & Sauropodomorpha indet. \\
\hline & & Nambalia roychowdhurii & Neotheropoda indet. \\
\hline & & Jaklapallisaurus asymmetrica & \\
\hline & & Guibasauridae indet. & \\
\hline \multicolumn{4}{|l|}{ SYNAPSIDA } \\
\hline Dicynodontia & - & cf. Ischigualastia & - \\
\hline \multirow[t]{2}{*}{ Cynodontia } & Exaeretodon statisticae & - & - \\
\hline & Deccanodon maleriensis & & \\
\hline
\end{tabular}

RoyChowdhury, 1996, Bandyopadhyay, 2016). This formation is a sandstone-dominated unit that contains subordinate amount of mudstone. The Rhaetian faunal assemblage contains 8 taxa (Table 2), comprising a ptychoceratodontid, a xenacanthid (Nath and Yadagiri, 2007; Prasad et al., 2008), a derived phytosaur similar to Nicrosaurus, an aetosaurid similar to Paratypothorax (Kutty et al 2007; Bandyopadhyay, 2011), several sauropodomorphs, and a neotheropod (Novas et al., 2011).

Another Late Triassic Gondwana horizon that is rich in varied vertebrate fossils is the Tiki Formation of the Rewa Basin (Fig. 7AP). It has yielded a diverse fish assemblage comprising hybodontid and xenacanthid sharks, dipnoans and actinopterygians (Prasad et al., 2008; Ray et al., 2016; Bhat and Ray, 2018; Bhat et al., 2018a, b) a metoposaurid, Panthasaurus maleriensis (Sengupta, 2002; Chakravorti and Sengupta, 2019), various diapsids including the rauisuchid Tikisuchus romeri and the rhynchosaur Hyperodapedon tikiensis (Chatterjee and Mazumdar, 1987; Mukherjee and Ray, 2014). Numerous archosauriform teeth belonging to 12 distinct morphotypes have been reported from the Tiki Formation (Ray et al., 2019). These include Galtonia, Protecovasaurus, aetosaur, indeterminate archosauriforms and theropod-like forms. Recently Datta et al. (2019a) reported numerous isolated teeth of a possible leptosuchomorph-grade phytosaur. Moreover, review of the skull earlier identified as Parasuchus from the Tiki Formation (Chatterjee 1978) is found to have belonged to a a new mystriosuchine phytosaur Volcanosuchus statisticae (Datta et al. 2019b). The formation has also yielded fragmentary remains of a saurischian dinosaur (Ray et al., 2016) and small theropod-like ungual phalanges (Rakshit et al., 2018). It may be noted that putatively the earliest lizard Tikiguania estesi (Datta and Ray, 2006) was reported from this formation. However, Hutchinson et al. (2012) questioned the provenance and geologic horizon of Tikiguania because it is almost indistinguishable from living agamids and suggested that the fossil might have come from younger horizons. As Tikiguania was extracted from the Tiki mudstones, which have yielded a rich microvertebrate fauna (Bhat, 2018; Bhat et al., 2018a, b; Bhat and Ray, 2018; Rakshit et al., 2018; Ray et al., 2019), such contamination hypothesis seems less likely (Chatterjee et al., 2017). However, unless more conclusive evidence is available, the taxon is excluded from the Tiki faunal list (Table 3). The formation has also yielded various non-mammalian cynodonts including a large traversodontid Ruberodon roychowdhurii (Ray, 2015), a small non-mammalian cynodont Rewaconodon tikiensis (Datta et al., 2004), a morganucodontid mammal Gondwanadon tapani (Datta and Das, 1996) and, one of the earliest 'nontherian' mammals Tiktherium, which is characterized by transversely expanded molar (Datta, 2005).

\section{Triassic Intercontinental Relationships}

\section{Early Triassic Global Correlation}

The Panchet fauna virtually duplicates the Early Triassic faunas 

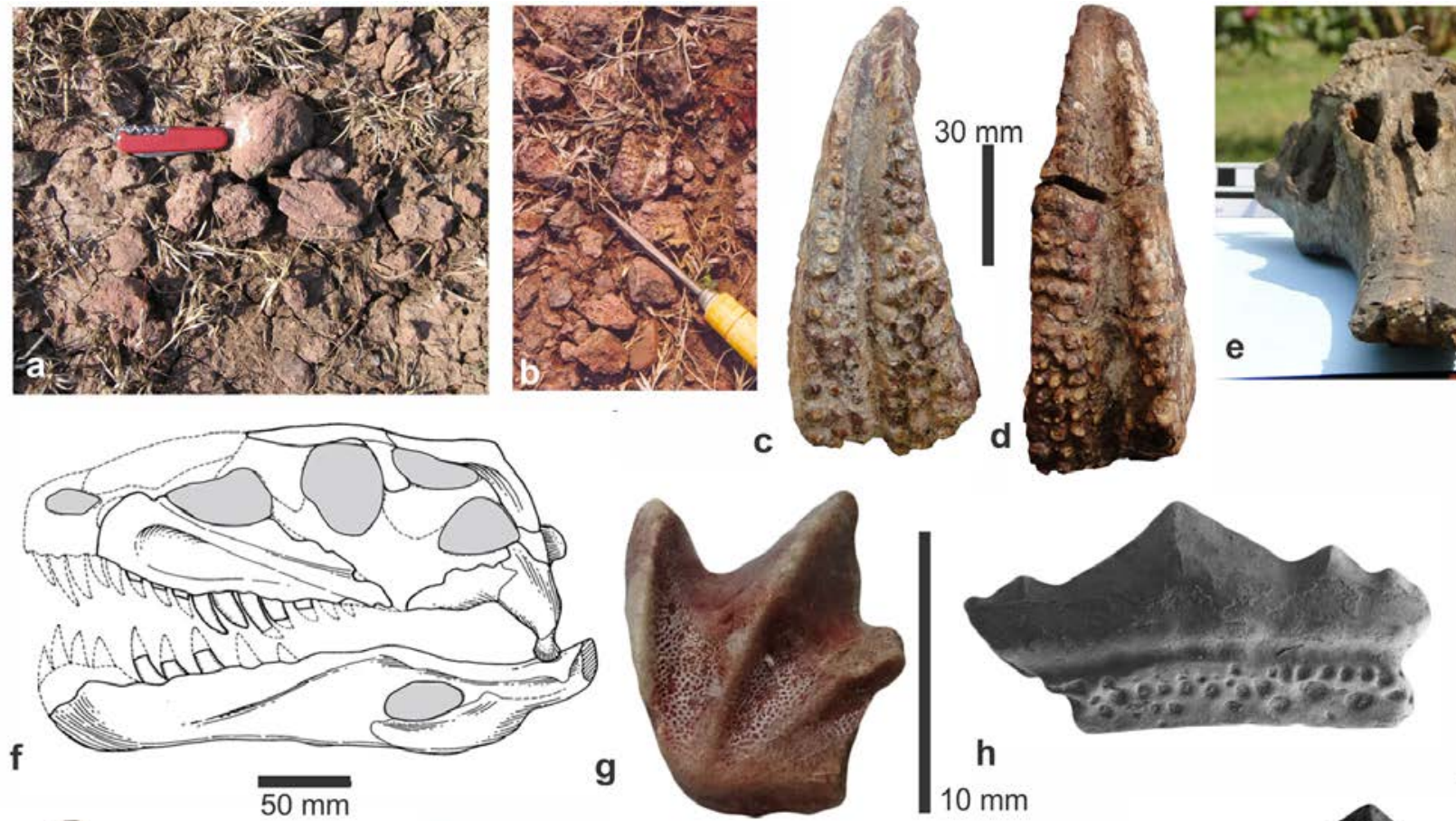

h
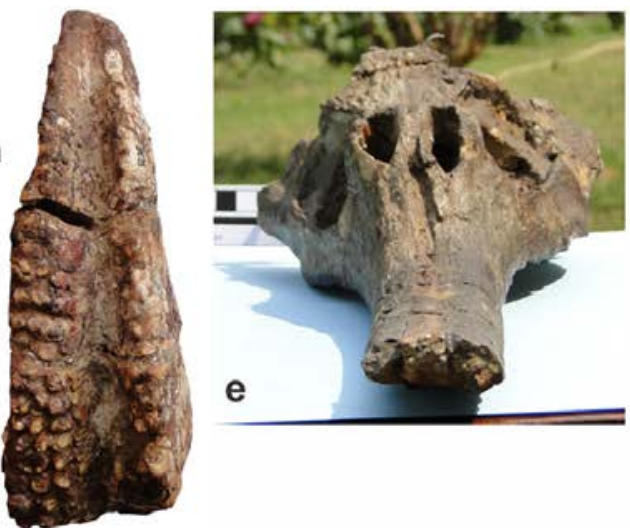

$0 \mathrm{~mm}$
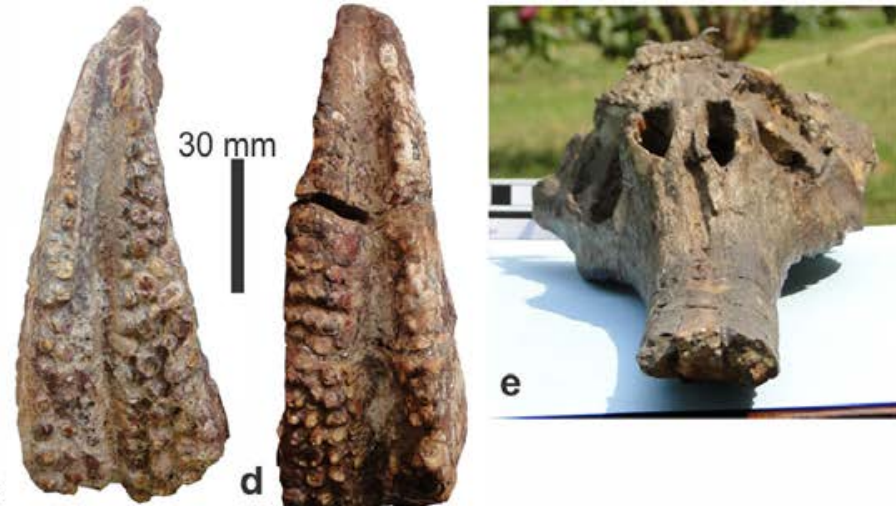
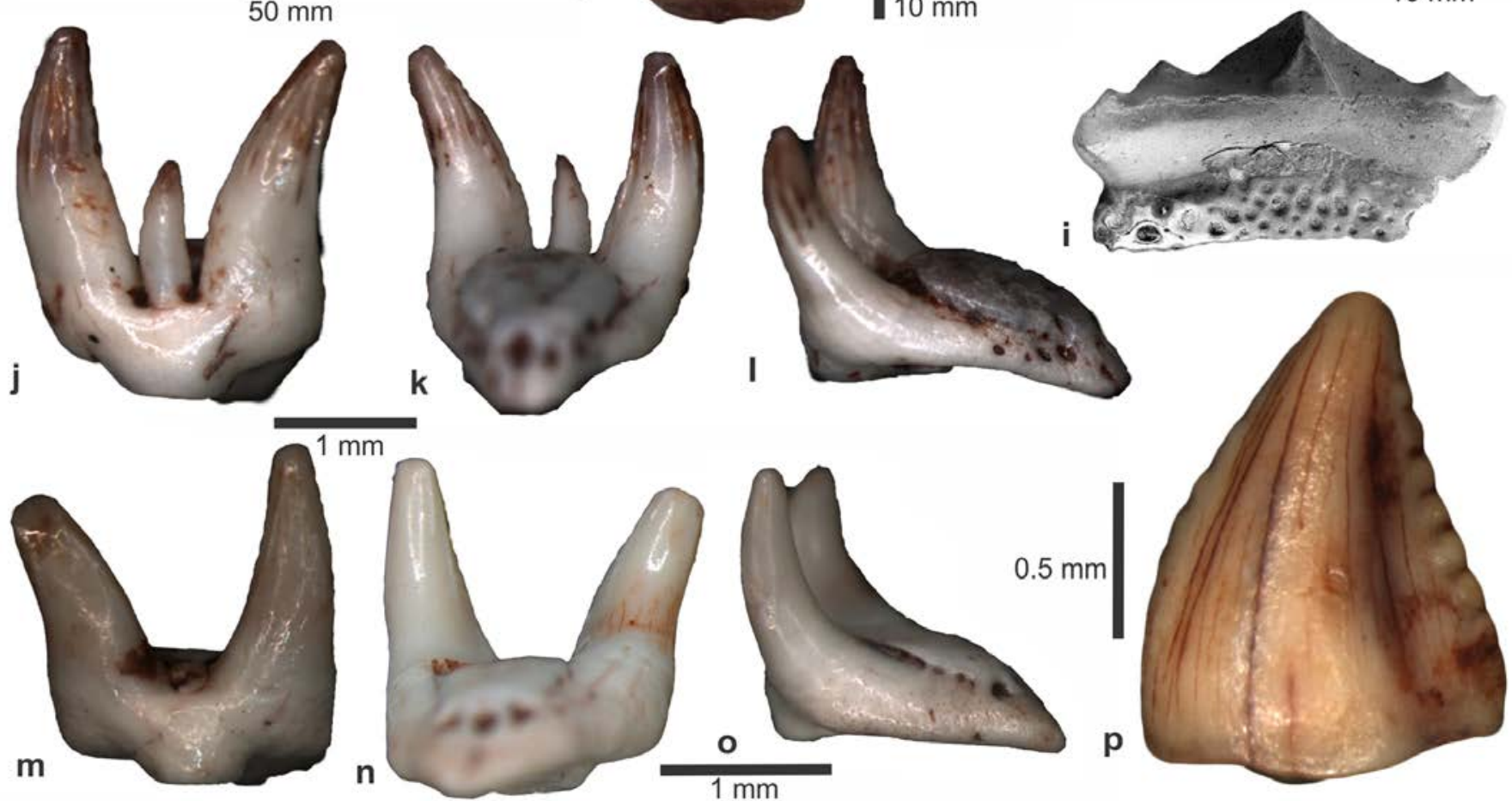

Figure 7. Vertebrates from the Late Triassic Tiki Formation of India. A-B, scattered fossils in the field; C-D, Hyperdapedon tikiensis Mukherjee and Ray (2014). Maxillary dental batteries in ventral views; E, Volcanosuchus statisticae Datta et al. (2019b). A partial skull in anterior view; F, Tikisuchus romeri Chatterjee and Mazumdar (1987). Restored skull and lower jaw; G-P, isolated teeth of G Ptychoceratodus oldhami Bhat and Ray (2018) in ventral view; H-I, Pristrisodus tikiensis Bhat et al. (2018a) in H, labial and I, lingual views; J-O, xenacanthid, $J-L$, Xenacanthus jaini and M-O, Xenacanthus indicus (Bhat et al., 2018b) in labial, lingual and side views; P, an archosauriform tooth in labial view (Bhat, 2018).

of South Africa, Antarctica, Russia and China, showing similar faunal associations, and suggesting a Pangaean vertebrate assemblage (Bandyopadhyay, 2011). Although the earliest Lystrosaurus ( $L$. maccaigi) is known from the latest Permian Dicynodon AZ (Smith and Ward, 2001), typical Lystrosaurus species including L. murrayi and L. curvatus appeared in the earliest Triassic Lystrosaurus AZ
(Smith et al., 2012) and hence may be correlated with the Panchet Formation. In addition, the Panchet fauna may be correlated with other Lystrosaurus-bearing horizons such as the Kamthi Formation of the P-G Basin, the N'tawere Formation of Zambia and the Lower Fremouw Formation of Antarctica (Fig. 8).

The Lystrosaurus - Thrinaxodon - Proterosuchus association is 
Table 3. Vertebrate fossil assemblage of the Late Triassic Tiki Formation of the Rewa Gondwana Basin, India. Sources of information: Datta and Das (1996), Datta (2004), Mukherjee and Ray (2014), Ray et al. (2016, 2019), Bhat and Ray (2018), Bhat et al. (2018a, b), Rakshit et al. (2018), Datta et al. $(2019 a, b)$.

\begin{tabular}{llll}
\hline Order/Family & Genus and species & Order/Family & Genus and species \\
\hline CHONDRICHTHYIS & DIAPSIDA & \\
Lonchididae & $\begin{array}{l}\text { Ponchidion estesi } \\
\text { Lonchidion incumbens } \\
\text { Pristrisodus tikiensis }\end{array}$ & Volcanosuchus statisticae \\
& Mooreodontus indicus & Rhynchosauria & Hyperodapedon tikiensis \\
Xenacanthidae & Mooreodontus jaini & Rauisuchidae & Tikisuchus romeri \\
& Tikiodontus asymmetricus & Rhynchocephalia & Undescribed \\
& Archosauriformes & Galtonia sp., Protecovasaurus \\
sp., other indeterminate forms & Undescribed \\
OSTEICHTHYIS & Ceratodus sp. & Dinosauriformes & Theropod-like(?) forms \\
Ptychocerato-dontidae & Ptychoceratodus oldhami & Aetosauria & Undescribed \\
Gnathorhizidae & Gnathorhiza sp. & SYNAPSIDA & Ruberodon roychowdhurii \\
Actinopterygii & Undescribed & Rewaconodon tikiensis \\
AMPHIBIA & Panthasaurus maleriensis & Mammaliaformes & Tikitherium copei \\
Metoposauridae & Gondwanadon tapani & \\
\hline
\end{tabular}

well known from the Lystrosaurus AZ of the Beaufort Group of South Africa and the Fremouw Formation of Antarctica (Kitching et al., 1972; Colbert and Kitching, 1977). However, the temnospondyl fauna of the Panchet Formation is more diverse as well as cosmopolitan. There are six or seven temnospondyl families in contrast to only two or three species of Lystrosaurus, a species of Proterosuchus, and two cynodont taxa although the abundance of Lystrosaurus far exceeds that of the other taxa. Based on these tetrapods, the Panchet fauna may be correlated with the Arcadia Formation of Australia, Knocklofty Formation of Tasmania, the Wordie Creek Formation of East Greenland, the Wupatki and Torrey members of the Moenkopi Formation of USA, and the Puesto Viejo and Rio Mendoza formations of Argentina. The age of the Panchet Formation is considered as Early Triassic (Induan-Early Olenekian; Cosgriff, 1984; Ray, 2005, 2015). The abundance of small Lystrosaurus specimens from the Kamthi Formation points towards correlation with the Lystrosaurus AZ of the Beaufort Group of South Africa, suggesting that the Kamthi Formation may be considered as Early Triassic in age. The specific identification of these Lystrosaurus specimens is not possible because of their fragmentary condition. A distinct time gap is envisaged between the Early Triassic Kamthi Formation and the underlying Kundaram Formation, which is Late Permian (early Lopingian, Wuchiapingian) in age (Fig. 1B).

\section{Middle Triassic Global Correlation}

With the beginning of the Triassic period, Lystrosaurus, became the most common tetrapod immediately after the end-Permian extinction event, and rapid turnover gave way to the archosauromorphs (Sahney and Benton, 2008). In the Pangaean scenario, the diversity of the once dominant temnospondyls and herbivorous synapsids started to decline at the beginning of the Middle Triassic and simultaneously the diapsids continued to flourish. However, the Middle Triassic continental vertebrates are comparatively less well represented because of the worldwide increase in marine conditions, especially in Laurasia (Gandin et al., 1982; Hallam, 1992). In terms of climate the Middle Triassic period was fairly hot and moist with alternate wet monsoon and dry seasons (Robinson, 1973; Tucker and Benton, 1982; Preto et al., 2010). Temnospondyl amphibians are the most common vertebrate fossils in many Middle Triassic assemblages and diverse archosauromorphs as well as archosaurs also started to flourish. The important Middle Triassic vertebrate horizons of Laurasia include the Holbrook and the Anton Chico members (Anisian) of the Moenkopi Formation in USA (Schoch et al., 2010), much of the Buntsandstein in Central Europe (Gradstein et al., 2012), the Dongus and Bukobay formations of Russia (Sennikov, 1996), GrenzbitumenZone of Switzerland (Röhl et al., 2001), the Otter Sandstone and the Bromsgrove Sandstone formations of United Kingdom (Milner et al., 1990), the Er-ma-ying Formation of Shanxi and Inner Mongolia (Zhang et al., 2003; Sues and Fraser, 2010; Sookias et al., 2014), and the Karamay Formation of Xinjiang, China (He et al., 2014). The most important Middle Triassic vertebrate yielding horizon in Gondwana is the Manda Formation of Tanzania (Cox, 1991; Lucas, 1998); it has produced a large number of Middle Triassic vertebrates. The other horizons are the Omingonde Formation of Namibia (Keyser, 1973; Pickford, 1995; Abdala and Smith, 2009), the N'tawere Formation of Zambia (Catuneanu et al., 2005; Rubidge, 2015), the Arcadia Formation, and the Hawkesbury and Wianamatta formations of Australia (Banks, 1978; Warren, 2012).

Jain et al. (1964) considered the age of Yerrapalli Formation as late Early Triassic or possibly early Middle Triassic. Later, with the recovery of the kannemeyeriid dicynodont (Roy Chowdhury, 1970; Bandyopadhyay, 1988a), and the stenaulorhynchine rhynchosaur (Chatterjee 1980), the formation was correlated with the Manda Formation of Tanzania, N'tawere Formation of Zambia, the Donguz Series of Russia, and the Omingonde Formation of Namibia, and an Anisian age for the Yerrapalli Formation was suggested by Bandyopadhyay (1988b) and Bandyopadhyay and Sengupta (1999, 2006). The other fossil-bearing Middle Triassic horizon of India, the Denwa Formation of the Satpura Basin, has not yielded any non- 


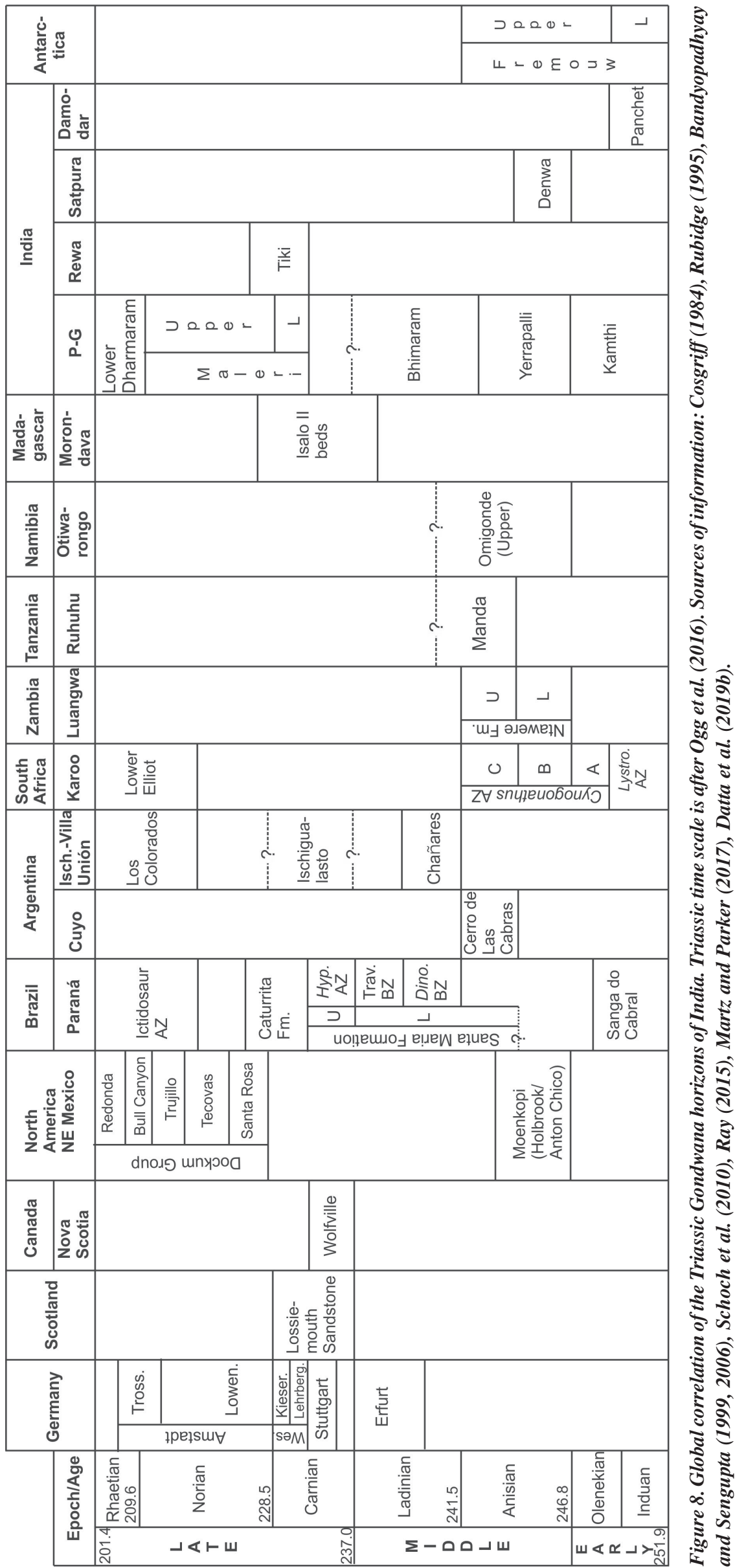

Episodes Vol. 43, no. 1 
mammalian cynodonts. Bandyopadhyay and Sengupta (1999) correlated it with the Holbrook Member of the Moenkopi Formation, U.S.A (Fig. 8). However, Abdala et al. (2005) directly correlated subzone C of the Cynognathus AZ of South Africa with the Denwa Formation based on the presence of Paracyclotosaurus, and considered the possible extension of the age to the latest Anisian based on the presence of two mastodonsaurids. Recently, a new capitosaurid temnospondyl, Antarctosuchus, a sister taxon to the Indian form Paracyclotosaurus crookshanki, has been described from the upper Fremouw Formation of Antarctica (Sidor et al., 2014). Based on this fossil fauna, the age of the Denwa Formation is considered as Anisian (Bandyopadhyay and Sengupta, 1999; Sengupta et al., 2016, 2017).

\section{Late Triassic Global Correlation}

The faunal records of Late Triassic horizons of the world are comparatively rich and complete. A variety of diapsids, including dinosaurs, emerged during this time and diversified throughout the world. Simultaneously temnospondyls and several amniotes faced extinction. A number of major tetrapod taxa such as metoposaurids, phytosaurs, aetosaurs, rauisuchids, poposaurids, trilophosaurs, diademodontids, traversodonts, chiniquodontids appeared in the Late Triassic, became the indigenous taxa of this time and disappeared by the end of the Triassic. Almost all the major group of extant terrestrial tetrapods, such as dinosaurs (including birds), pterosaurs, crocodylians, turtles, lepidosaurs, extant amphibians (frogs, salamanders and caecilians) evolved by the end of Triassic. The first mammaliaforms (Rowe, 1988) appeared during the Late Triassic. The appearance of dinosaurs and mammaliaforms near its close makes the Triassic a transitional period between the archaic tetrapods of the Palaeozoic, the rise and fall of the dinosaurs during the Mesozoic and the spectacular radiation of mammaliaforms during the Cenozoic.

In terms of climate the Late Triassic period had fairly moist and hot climate of monsoon type with an alternation of wet and dry seasons (Robinson, 1970; Preto et al., 2010). A significant episode of increased rainfall throughout the world took place during this time, especially at the boundary between the lower and upper Carnian (Preto et al., 2010). Subsequently, the late Carnian and Norian became climatically stable with some minor climatic changes. In Laurasia, a large number of Late Triassic faunas is known from the Chinle Formation of southwestern United States, Dockum Formation of Texas, Popo Agie Formation of Wyoming and Newark Group of eastern United States (Long and Murry, 1995; Heckert, 2004; Lucas, 2018), Keuper Group of Germany (Deutsche Stratigraphische Kommission, 2005; Gradstein et al., 2012), and Krasiejów and Lisowice of Poland (Dzik and Sulej, 2007; Dzik et al., 2008). Among the Gondwana continents the Late Triassic vertebrates are known from the Ischigualasto, Los Colorado and Cacheuta formations of Argentina (Bonaparte, 1978; Tucker and Benton, 1982; Rogers et al., 1993; Arcucci et al., 2004), Santa Maria and Caturrita formations of Brazil (Langer, 2007; Langer et al., 2018), Lower Elliot Formation of South Africa (Yates, 2003), Isalo II Beds of Madagascar (Flynn et al., 1999; Fortuny et al., 2019) and Argana Group of Morocco (Dutuit, 1972; Buffa et al., 2019).

In the current work, the post-Carnian age for the Chinle Formation in Arizona and New Mexico are considered based on radioisotopic data (Irmis et al., 2010, 2011; Olsen et al., 2011; Martz et al., 2013), where Otischalkian and Adamanian are early Lacian (early Early
Norian) and late Lacian (late Early Norian), respectively (Martz and Parker, 2017). Moreover, the Carnian-Norian boundary falls at about $228 \mathrm{Ma}$, and the duration of the Norian stage was long and comprises c.20 Ma (Gradstein et al., 2012; Ogg et al., 2016). Proliferation of Hyperodapedon in the lower Maleri fauna (about 60\% of the total diversity, Benton, 1983) shows that it belongs to the Hyperodapedon biochron (sensu Lucas and Heckert, 2002) and the Ischigualastian LVF (sensu Langer, 2005), and a Carnian age was suggested for the formation (Langer, 2005). The lower Ischigualasto Formation of Argentina where Hyperodapedon dominated has been dated at 231.4 0.3 Ma (Martínez et al., 2011), i.e., late Carnian (Gradstein et al., 2012; Schultz et al., 2016). Langer et al. (2017) hence suggested a late Carnian to earliest Norian age for the horizons where Hyperodapedon is abundant, including the lower Maleri Formation. Although the lower Maleri Formation has yielded aetosaurian remains (Bandyopadhyay, 2011) these are yet to be studied in details. On the other hand, the metoposaurid temnopondyls are not robust Late Triassic biomarkers (Martz and Parker, 2017) as these have a long range extending from middle/late Carnian to middle/late Norian. Moreover, their global distribution is genera-specific as Koskinonodon and Apachesaurus are known from Noth America, Metoposaurus is from Europe, Arganasaurus and Dutuitosaurus is from Morocco and Panthasaurus from India (Chakravorti and Sengupta, 2019; Bufa et al., 2019). However, presence of Exaeretodon (Chatterjee, 1982) suggests a Late Carnian age for the lower Maleri Formation as this genus is essentially known from the late Carnian Hyperodapedon AZ of Santa Maria Formation of Brazil (Langer et al., 2007), and the Ischigualasto Formation of Argentina (Abdala and Ribeiro, 2010). In addition, the lower Maleri Formation is correlated with the Isalo II Beds (Madagascar), the Lossiemouth Sandstone (England), and the Middle Keuper (Germany, Fig. 8).

It is to be noted that the Bhimaram Formation, underlying the Maleri Formation is poorly fossiliferous and has yielded fragmentary remains of temnospondyl amphibians and dicynodonts (Kutty et al., 1987). Bandyopadhyay and Sengupta (2006) assigned an age of Middle Triassic (late Anisian to Ladinian) to the formation. Hence, a distinct age gap is evident between the Bhimaram Formation and the overlying lower Maleri Formation.

The upper Maleri Formation has yielded a diverse assemblage, including different sauropodomorphs. This distinctly younger upper Maleri fauna may be correlated with the Lower Elliot Formation of South Africa, lower part of the upper Mackay Formation of Madagascar, and lower parts of the Rio Blanco and Los Colorados Formation, Argentina (Fig. 8). An early Norian age has been proposed for this upper Maleri fauna (Bandyopadhyay, 2011). Although an age gap was suggested between the lower and upper fauna of the Maleri Formation (Langer, 2005), later workers (Bandyopadhyay and Sengupta, 2006; Bandyopadhyay, 2011) did not support this view (Ray, 2015).

The fossil assemblage of the lower Dharmaram Formation is essentially an archosaur-dominated tetrapod fauna, which is distinctly different from that of the underlying upper Maleri Formation. The lower Dharmaram fauna resembles post-Ischigualastian assemblages, such as that of the La Esquina Fauna of the Los Colorados Formation, the Trossingen Formation of the German Keuper, the lower Elliot Formation and the Chinle Formation, and is probably latest NorianRhaetian in age (Bandyopadhyay and Sengupta, 2006; Kutty et al., 2007; Novas et al., 2011; Bandyopadhyay, 2016).

An association of Hyperodapedon, the derived phytosaurs 
including Volcanosuchus and Panthasaurus is found in the Tiki Formation of the Rewa basin. Based on its palynofloral assemblage (Maheswari and Kumaran, 1979) and faunal content (Bhat, 2018 and references therein), the Tiki Formation has been correlated with the lower Maleri Formation of the P-G Basin (Lucas, 1998; Datta, 2004) and the Camp Springs Member of the Dockum Formation, U.S.A. (Datta et al., 2004). A Carnian age was suggested for the Tiki Formation (Datta, 2004; Mukherjee et al., 2012). It is evident that the Tiki fauna may be placed within the Hyperodapedon biochron (Lucas and Heckert, 2002) and the Ischigualastian LVF (Langer, 2005) based on the abundance of Hyperodapedon in the fauna (Mukherjee and Ray, 2012). Ray (2015) showed that the Tiki Formation may be correlated with other horizons such as the lower part of the Pebbly Arkose Formation, Zimbabwe, base of the Isalo II Beds (Mackay Formation) of Madagascar, upper part of the Alemoa Member of the Santa Maria Formation, Brazil, Wolfville Formation of Nova Scotia and Popo Agie Formation of Wyoming (Fig. 8). Recently, a rich assemblage of freshwater sharks, ceratodontiform dipnoans, xenacanthids, and actinopterygians, and varied archosauriform teeth has been reported, and shows similarity in faunal assemblage with that of the lower Tecovas Formation of the Chinle Group (Ray et al., 2016; Bhat et al., 2018a, b), which is early/middle Norian in age (Martz and Parker, 2017). Moreover, Datta et al. (2019a, b) reported the presence of more derived phytosaurs and absence of the basal Parasuchusi from the formation. Hence, a late Carnian to early/middle Norian age is proposed for the Tiki Formation.

\section{Jurassic Vertebrate faunas}

\section{Faunal Characteristics}

The end-Triassic witnessed an extinction event which is considered as one of largest of the five major extinction events (Benton, 1986; Olsen and Sues, 1986, Whiteside et al., 2010). At the onset of the Jurassic when the supercontinent Pangaea started to break up, world continued to be warm and arid in low- to mid- latitudes in western Pangaea as indicated by the high latitude floras in Siberia and lack of glacial deposits. While in the Late Jurassic this arid zone spread towards southern Eurasia (Hallam, 1984). Sea levels began to rise because of increase in sea-floor spreading and subsequently large areas of the continents were flooded, the deserts began to retreat, and continental temperatures stabilized (Tennant et al., 2016). The typical Dicroidium-Ptilophyllum flora of the Gondwana was replaced by a conifer-benettetilean flora of the Jurassic (Chatterjee et al., 2017). A short-lived but widespread marine transgression at the beginning of Jurassic resulted in advancement of shallow seas across the continents (Haq, 2017), as a result of which the Early Jurassic terrestrial fossil record is scarce (Tennant et al., 2016). India is no exception and the terrestrial tetrapods of the Jurassic period are found only from P-G Basin (Bandyopadhyay, 1999). There are two horizons, which have produced Early Jurassic vertebrates, and these included the Kota Formation and the underlying upper part of the Dharmaram Formation (Bandyopadhyay and Roychowdhury, 1996). The upper Dharmaram fauna includes two sauropodomorphs, Lamplughsaura dharmaramensis and Pradhania gracilis, a theropod similar to Dilophosaurus, and a sphenosuchid similar to Dibothrosuchus (Kutty et al., 2007).

The overlying Kota Formation has been subdivided into two lithological units (Rudra, 1982); the lower unit is dominated by fluviatile sandstone-mudstone association while the upper part includes marl and limestone beds. Rudra and Maulik (1994) suggested that a meandering river system deposited the lower Kota and a braided river system formed the upper part. Interestingly two distinct biozones have been identified, where the lower fauna contains two sauropods, Barapasaurus tagorei (Fig. 9A) and Kotasaurus yamanpalliensis (Fig. 9B-C), an ankylosaur (Galton, 2019), a kuehneotheriid, an amphilestid, and a morganucodontid (Table 4). From the limestone of the upper part of the Kota Formation a diverse vertebrate fauna has been reported, which includes three semionotid genera, two pholidophorids, a coelacanthid, a kayentachelyid, a campylognathoidid, two sphenodontians, and a lepidosaur. In addition, there are seven mammaliaformes (Table 4) including two docodontids, a morganucodontid, and an amphilestid (Bandyopadhyay et al., 2010). The fauna also contains three mammaliaformes of uncertain affinities (Table 4).

\section{Intercontinental relationships}

Early Jurassic tetrapod assemblages are known from the McCoy Brook Formation of Nova Scotia, Canada (Sues et al., 1994; Fedak et al., 2015), Moenave, Kayenta and Navajo formations, Arizona, in USA(Schoch et al., 2010), La Boca Formation of Tamaulipas, Mexico (Clark et al., 1994), and Lufeng Formation of Yunnan, China (Lucas 2009). In the Gondwanan region, the Elliott and Clarens formations of South Africa (Knoll, 2005) and the Fallan Formation of Antarctica (Hammer and Hickerson, 1996) are known for their Early Jurassic vertebrates. The sedimentary succession of the Cañadón Asfalto continental basin in the Argentinean Chubut Province of central Patagonia preserves a rich record of Jurassic vertebrate fauna. A sauropod-dominated fauna occurs in the Las Leoneras Formation, which is Early Jurassic (Sinemurian to Pliensbachian) in age (Pol et al., 2011). The next stratigraphically higher fauna occurs in the EarlyMiddle Jurassic Cañadón Asfalto Formation (Cúneo et al., 2013). The Morrison Formation of USA (Foster, 2003) and the Tendaguru Beds of Tanzania (Remes, 2007) are well known for their Late Jurassic vertebrate fossils. However, most of the Early Jurassic vertebratebearing horizons of Europe are marine deposits (Delsate and Ezcurra, 2014).

In the light of studies on faunal turnover during Triassic-Jurassic boundary by Olsen and Galton (1977) and Benton (1986), the upper Dharmaram fauna represents the record of earliest Jurassic tetrapods and a Hettangian age was assigned to the formation (Bandyopadhyay and RoyChowdhury, 1996; Bandyopadhyay and Sengupta, 2006). The fauna consists of two basal sauropodomorphs, a sphenosuchian similar to Dibothrosuchus of the Lower Jurassic Lufeng Group, China and a large theropod similar to Dilophosaurus of the Lower Jurassic Kayenta Formation, Arizona (Kutty et al., 2007; Novas et al., 2011). These authors further stated that the upper Dharmaram fauna is similar to the faunas from the Upper Elliot and Clarens formations of South Africa, the Kayenta Formation of USA and the lower Lufeng Group of China, and suggested an Early Jurassic age (Sinemurian) for this horizon. On the other hand, the Kota Formation has long been considered to be of Liassic age (King, 1881; Robinson, 1970) on the basis of its varied fish assemblage. Analyzing the faunas of the lower and upper units of the Kota Formation and comparing them with faunas from coeval horizons, Bandyopadhyay and Roychowdhury (1996) and Bandyopadhyay and Sengupta (2006) assigned the lower Kota fauna to an age ranging from Sinemurian to Pliensbachian and 

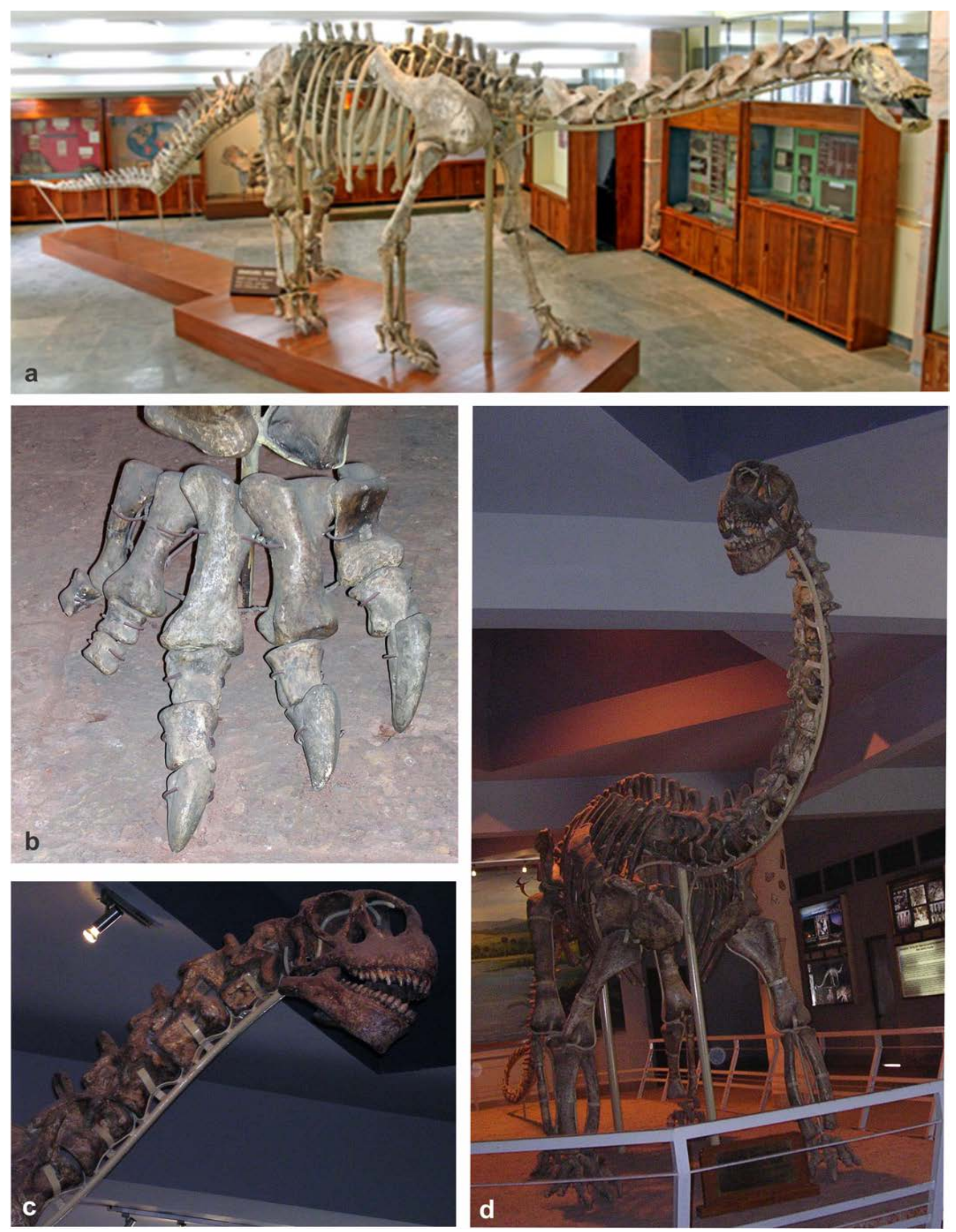

Figure 9. Sauropod dinosaurs of the Kota Formation, A-B, Barapasaurus tagorei, A, a mounted skeleton; B, mounted manus in anterior view; $C-D$, Kotasaurus yamanpalliensis, $C$, mounted neck and skull; $D$, a mounted skeleton. 
Table 4. Vertebrate fossil assemblage of the Jurassic Kota Formation of India (after Bandyopadhyay et al., 2010; Parmar et al., 2013, Galton, 2019)

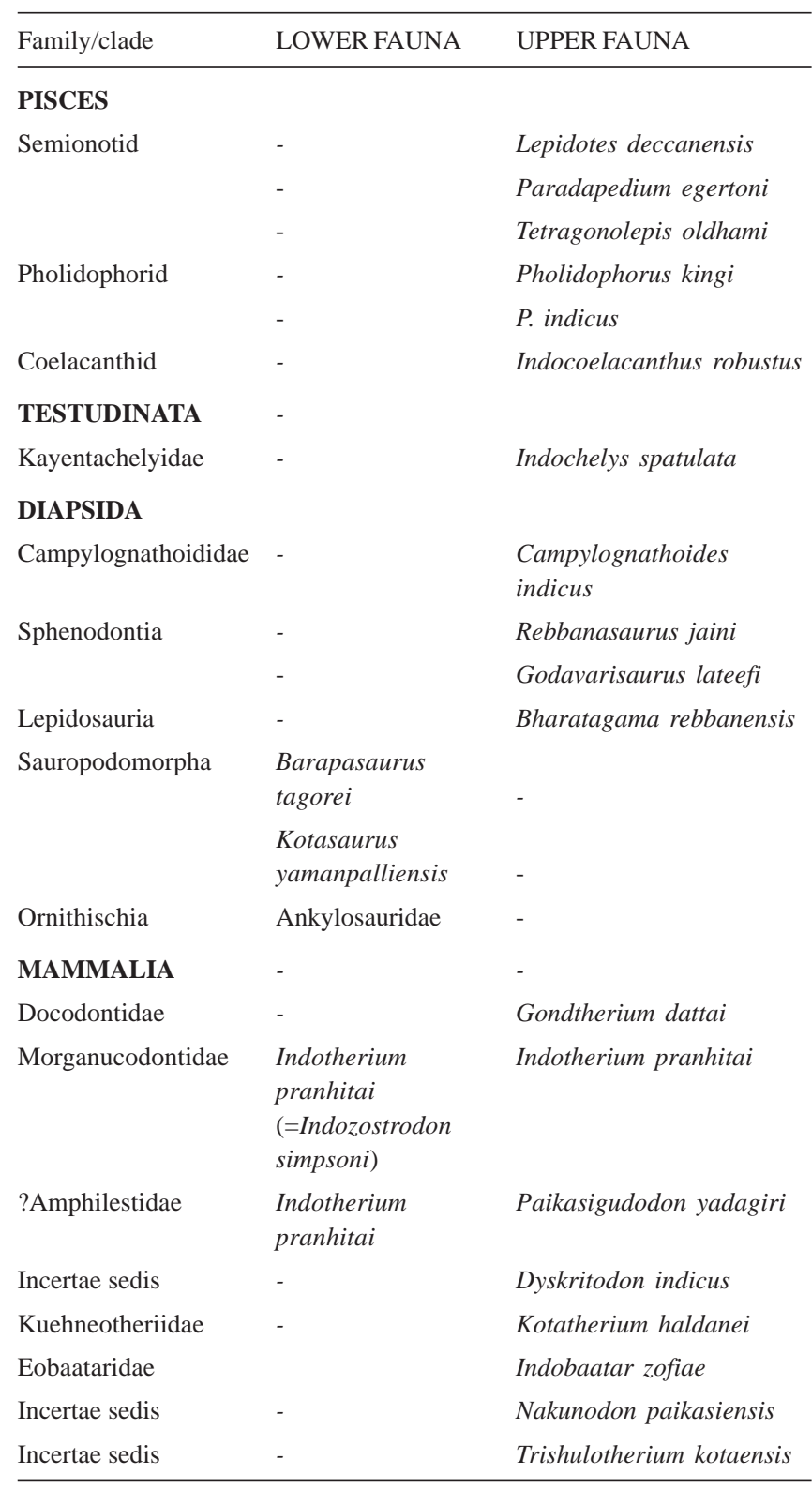

the upper Kota fauna to Toarcian, which may be extended to the Middle Jurassic (?Aalenian).

\section{Discussion and Concluding Remarks}

In the backdrop of a Pangaean landscape, certain macroevolutionary patterns and major transformations of vertebrate evolution, especially of the tetrapods, are evident in the highly diverse Gondwana fossil records of India. During the Late Permian, the dicynodont-dominated fauna of the Kundaram Formation closely resembles the dicynodont radiation in other Gondwanan regions, especially the Beaufort Group of the Karoo Supergroup, South Africa (Ray, 1999). The Permian-Triassic boundary in India is represented by the transition from the Kundaram to the Kamthi formations of PG Basin and from the Raniganj to the Panchet formations of the Damodar Basin. The generic diversity of the dicynodonts decreased drastically at the onset of the Triassic (Fig. 10) as Lystrosaurus is the only known genus from the Panchet and Kamthi formations. This steady decrease is also true for the synapsid (excluding the early mammals) diversity. Although collection bias cannot be ruled out, such decrease in taxic diversity is correlated with the end-Permian mass extinction, which resulted at least in part from a large scale destabilization of carbon cycle (Bond and Grasby, 2017).

After the end-Permian extinction event, most of the ecological niches became almost vacant, as a result of which the Early Triassic exhibited a low faunal diversity, with Lystrosaurus, accounting > 90\% of the terrestrial vertebrates together with rare amphibians, but without diverse herbivores and top predators (Benton, 1983; Chen and Benton, 2012). However, Damiani et al. (2003) discovered a more diverse tetrapod assemblage from the Early Triassic Lystrosaurus AZ exposures in Barendskraal of South Africa. The capitosaurs and trematosaurids flourished during this period whereas the archosauriforms formed a minor component. A similar faunal transition is depicted by the Panchet fauna (Fig. 10), which shows a highly diverse temnospondyl radiation involving several families such as the trematosaurid, benthosuchid, rhytidosteid, lapillopsid, tupilakosaurid and brachyopid temnospondyls, which is comparable with that of other coeval Gondwanan and Laurasian regions. Mukherjee et al. (2010) suggested that the small size of the trematosaurids and Lystrosaurus (Shishkin et al., 1996; Ray, 2005) reflects the 'Lilliput effect' as documented by Twitchett (2007). Moreover, the fast growth strategy adopted by the trematosaurids was linked to the rapid invasion of various empty Panchet ecological niches in the aftermath of the end-Permian mass extinction (Mukherjee et al., 2010). The Panchet and Kamthi fauna may be considered as the late Palaeozoic 'holdover' fauna as described by Romer (1966) and Padian and Sues (2015).

A significant change occurred in the composition of terrestrial tetrapod communities during the Middle Triassic. The diversity and the number of archosauromorphs especially the rhynchosaurs increased considerably. Two principal lineages of Archosauria, Ornithodira and Crurotarsi and two groups of therapsids, kannemeyeriiform dicynodonts and gomphodont cynodonts, appeared and diversified considerably in the Gondwanan regions (Fraser and Sues, 2011). In India although a decrease in diversity at the temnospondyl family-level is evident during the Middle Triassic (Fig. 10), several new capitosaur taxa such as Paracyclotosaurus crookshanki and Cherninia denwai of the Denwa Formation appeared during this time. This period also witnessed the radiation of the dicynodonts, albeit in small numbers compared to the Late Permian diversity (Fig. 10) and is represented by several kannemeyeriiform taxa from the Yerrapalli and Denwa formations (Table 2). Moreover a decrease in dominance of the synapsids, and increase in diversity and radiation of the diapsids (archosauromorphs) in the form of rhynchosaurids, allokotosaurs, aphanosaurs and erythrosuchids (Fig. 10) is also noticed in this period.

During the Late Triassic, terrestrial ecosystems exhibited widespread and dramatic changes in the composition of vertebrate communities resulting in a biologically diverse fauna (Sues and Fraser, 2010; Irmis and Whiteside, 2011). Taxonomic richness was a rapidly ascending phenomenon whereas taxonomic relative abundances were qualitatively quite stable in the Late Triassic (Olsen et al., 2011). Morphological disparity was relatively high during this time (Brusatte et al., 2008) and evidence of high biogeographic provinciality was provided by Olsen et al., (2011) from the Norian-Rhaetian ChinleDockum assemblages and the Germanic basin type assemblages of 


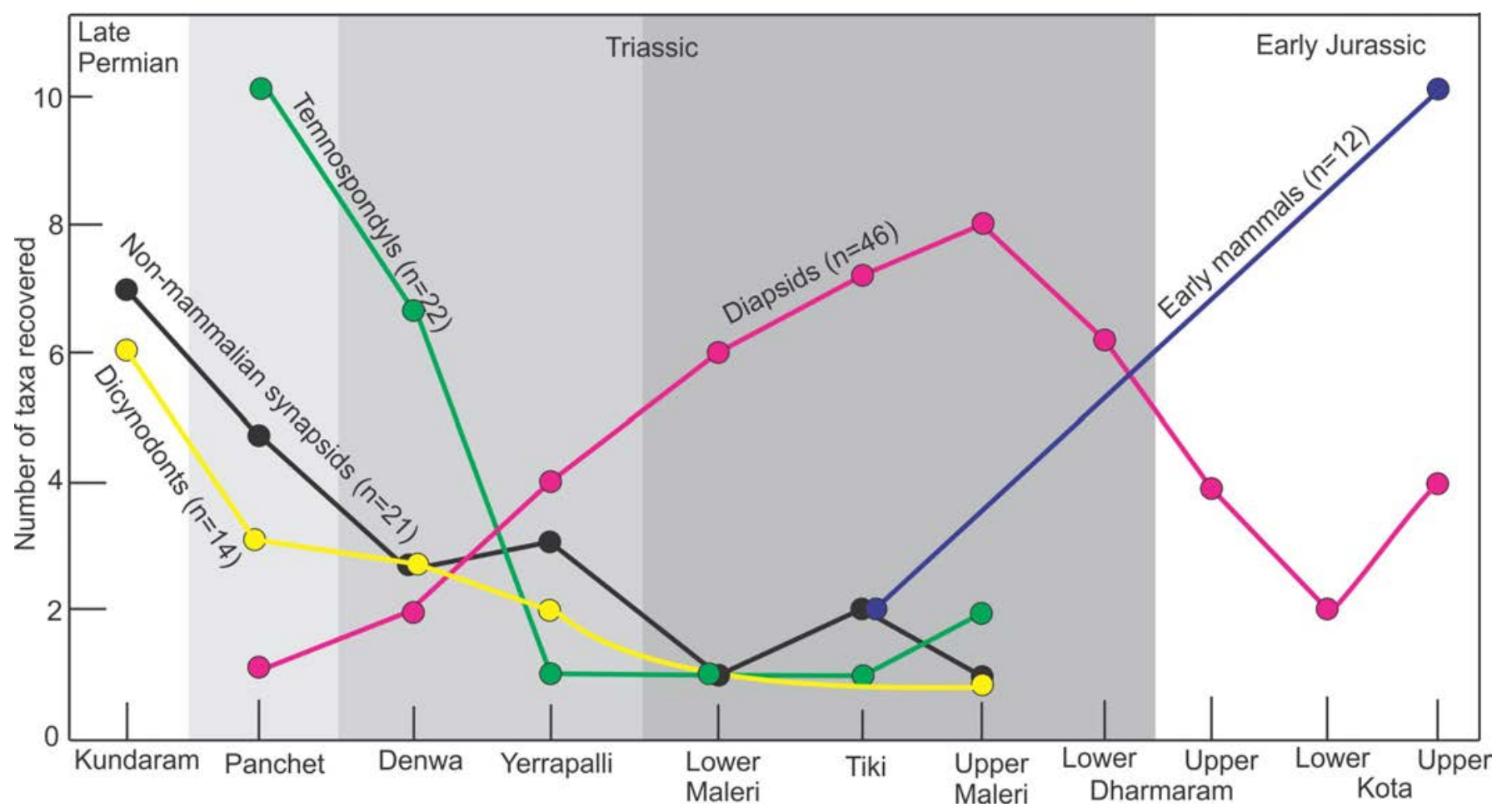

Figure 10. Graphical representation of the Permian-Jurassic taxic diversity in the different Gondwana stratigraphic horizons of India. Subsequently darker shades of grey indicate subdivision of the Triassic into Early, Middle and Late. Sources of information: Chatterjee (1980, 1982, 1987), Bandyopadhyay (1999, 2011), Ray (1999, 2001), Kutty et al. (2007), Novas et al. (2011), Kammerer et al. (2016), Mukherjee and Ray (2014), Chakravorti and Sengupta (2019), Ray et al. (2016, 2019).

the Central Europe and Greenland of Carnian-Rhaetian age. Both the 'archaic' and the 'modern' taxa are noted during the Late Triassic. The dicynodont therapsids, procolophonid parareptiles and chroniosuchian anthracosaurs represented the 'archaic'. The ancestors of modern tetrapod communities such as the crocodyliforms, lepidosaurs, mammaliaforms and turtles appeared during Late Triassic, along with the oldest frogs, salamanders and caecilians, dinosaurs, pterosaurs and mammals, which also had their origin during this period (Fraser and Sues, 2011). Similar high diversity and radiation of vertebrates are also seen in the Indian scenario, especially in the advent of different types of freshwater fishes (hybodontids, xenacanthids, actinopterygians and dipnoans), temnospondyls (metoposaurids and chigutisaurids) archosauromorphs (archosauriforms, phytosaurs and basal saurischians including sauropodomorphs), and cynodonts including the early mammaliaforms. This period is characterized by the appearances and disappearances of 'indigenous fauna' such as the phytosaurs and appearance of 'living' fauna (sensu Romer, 1966; Padian and Sues, 2015), which included the basal saurischians and mammaliaforms. The Late Triassic vertebrates of India comprise distinct faunal assemblages, which are more or less comparable to the global Triassic vertebrate faunachrons, especially of the Carnian (sensu Lucas, 1998, 2010; Gradstein et al., 2012; Tanner, 2018). The Triassic-Jurassic transition is marked by a distinct faunal change, where the phytosaurs and aetosaurs of the upper Maleri and lower Dharmaram changes to a new upper Dharmaram fauna comprising sphenosuchians (Bandyopadhyay and Sengupta, 2006). This marked biotic turnover may be correlated with the drastic climatic change at the Triassic-Jurassic transition, which experienced global warming because of a four-fold increase in atmospheric $\mathrm{CO}_{2}$ that probably derived from volcanism (Bond and Grasby, 2017; Tennant et al., 2017).
Hence, it may be concluded that the Late Permian-early Middle Jurassic Gondwanan vertebrates of India reflect major global faunal fluctuations and transitions, macroevolutionary patterns and constitute important biostratigraphic markers for global correlation of the Indian stratigraphic horizons.

\section{Acknowledgements}

We are thankful to Dr. Fareeduddin, Chair, Legacy Committee of 36th International Congress and Prof. G.V.R. Prasad of Delhi University, the Subject Editor who invited us to contribute an article for the proposed publication titled "Geodynamic Evolution of the Indian Subcontinent- Hadean to Recent”. We are indebted to late Prof. Tapan RoyChowdhury for introducing us to the world of Vertebrate Palaeontology. One of us (SB) thanks Prof. D. P. Sengupta of the Indian Statistical Institute, Kolkata, who shared his views on the Panchet fauna. SR thanks Mr. Debajit Datta of the Indian Institute of Technology, Kharagpur for drafting the geological map of the P-G Basin. The authors are thankful to Prof. H. D. Sues and another anonymous reviewer for their suggestions which has upgraded the paper. Finally, the authors are grateful to the authorities of the Indian Statistical Institute and the Indian Institute of Technology, Kharagpur for infrastructure facilities.

\section{References}

Abdala, F., and Ribeiro, A.M., 2010, Distribution and diversity patterns of Triassic cynodonts (Therapsida, Cynodontia) in Gondwana. Palaeogeography, Palaeoclimatology, Palaeoecology, v. 286, pp. 202-217. 
Abdala, F., and Smith, R.M.H., 2009, A Middle Triassic cynodont fauna from Namibia and its implications for the biogeography of Gondwana, Journal of Vertebrate Paleontology, v. 29, pp. 837851.

Abdala, F., Hancox, P.J., and Neveling, J., 2005, Cynodonts from the uppermost Burgersdorp Formation, South Africa, and their bearing on the biostratigraphy and correlation of the Triassic Cynognathus Assemblage Zone. Journal of Vertebrate Paleontology, v. 25, pp. 192-199.

Angielczyk, K.D., Sebastien, H., Smith, R.M.H., Tabor, N.J., Sidor, C.A., Steyer, J-S., Tsuji, L.A., and Gostling, N.J., 2014, New Dicynodonts (Therapsida, Anomodontia) and updated tetrapod stratigraphy of the Permian Ruhuhu Formation (Songea Group, Ruhuhu Basin) of Southern Tanzania. Journal of Vertebrate Paleontology, v. 34, pp. 1408-1426.

Arcucci, A.B., Marsicano, C.A., and Caselli, A.C., 2004, Tetrapod association and palaeoenvironment of the Los Colorados Formation (Argentina): a significant sample from western Gondwana at the end of the Triassic. Geobios, v. 37, pp. 557568.

Bandyopadhyay, S., 1988a, A kannemeyeriid dicynodont from the Middle Triassic Yerrapalli Formation. Philosophical Transaction of the Royal society of London, v. B320, pp. 185-233.

Bandyopadhyay, S., 1988b, Vertebrate fossils from the PranhitaGodavari valley of India with special reference to the Yerrapalli Formation. Modern Geology, v. 13, pp. 107-117.

Bandyopadhyay, S., 1999, Gondwana vertebrate faunas of India. Proceedings of the Indian National Science Academy, v. A65, pp. 285-313.

Bandyopadhyay, S., 2011, Non-marine Triassic vertebrates of India, In: Calvo, J.O., Porfiri, J., Gonzalez Riga, B., and Dos Santos, D. (Eds), Paleontología y dinosaurios desde América Latina. EDIUNC, Editorial de la Universidad Nacional de Cuyo, Mendoza, Argentina, pp. 33-46.

Bandyopadhyay, S., 2016, Glimpses of Triassic Life in India, Developments in Geosciences in the Past Decade. Emerging Trends for the Future and Impact on Society and Annual General Meeting of the Geological Society of India, Seminar Abstract Volume, Indian Institute of Technology, Kharagpur, India, p. 2832.

Bandyopadhyay, S., and Roy Chowdhury, T., 1996, Beginning of the continental Jurassic in India - a palaeontological approach. Museum of Northern Arizona, Bulletin, v. 60, pp. 371-378.

Bandyopadhyay, S., and Sengupta, D.P., 1999, Middle Triassic vertebrate faunas from India. Journal of African Earth Sciences, v. 29, pp. 233-241.

Bandyopadhyay, S., and Sengupta, D.P., 2006, Vertebrate faunal turnover during the Triassic Jurassic transition: an Indian scenario. In: Harris, J., Lucas, S.G., Spielmann, J.A., Lockley, M.G., Milner, A.R.C., and Kirkland, J.I. (Eds.), The Triassic - Jurassic Terrestrial Transition. New Mexico Museum of Natural History and Science Bulletin, v. 37, pp. 77-85.

Bandyopadhyay, S., Gillette, D.D., Ray, S., and Sengupta, D.P. 2010, Osteology of Barapasaurus tagorei (Dinosauria: Sauropoda) from the early Jurassic of India. Palaeontology, v. 53, pp. 533-569.

Banks, M.R., 1978, Correlation chart for the Triassic System of Australia. Bulletin of the Bureau of the Mineral Resources, v. 156C, pp. 1-46.

Barberena, M.C., Araujo, D.C., and Lavina, E.L., 1975, Late Permian and Triassic tetrapods of Southern Brazil. National Geographic Research 1985 Winter, p.5-20.

Barberena M.C., Araujo D.C., Lavina E.L., and Faccini U.F., 1991, The evidence for close paleofaunistic affinity between South America and Africa. In International Gondwana Symposium, 7,
São Paulo, 1988, Proceedings, p. 455-467.

Benton, M.J., 1983, The Triassic reptile Hyperodapedon from Elgin: functional morphology and relationships. Philosophical Transactions of the Royal Society of London, v. B302, pp. 605717.

Benton, M.J., 1986, The Late Triassic tetrapod extinction events. In: Padian, K. (Ed.), The beginning of the Age of Dinosaurs. Cambridge, Cambridge University Press, pp. 303-320.

Bernardi, M., Petti, F.M., Kustatscher, E., Franz, M., Hartkopf-Frçder, C., Labandiera, C. C., Wapler, T., van Konijnenburg-van Cittert, H. A., Peecook, B.R., and Angielczyk, K.D., 2017, Late Permian (Lopingian) terrestrial ecosystems: a global comparison with new data from the low-latitude Bletterbach Biota, Earth Science Reviews v. 175, pp. 18-43.

Bhat, M.S., 2018, A new assemblage of vertebrate microfossils from India: a window on Late Triassic biodiversity and palaeobiogeography. Unpublished Ph.D Thesis, Indian Institute of Technology, Kharagpur, 237pp.

Bhat, M.S., and Ray, S., 2018, A record of new lungfishes (Osteichthyes: Dipnoi) from the Carnian (Upper Triassic) of India. Historical Biology, https://doi.org/10. 1080/ 08912963.2018.1499020.

Bhat, M.S., Ray, S., and Datta, P.M., 2018a, A new hybodont shark (Chondrichthyes, Elasmobranchii) from the Upper Triassic Tiki Formation of India with remarks on its dental histology and biostratigraphy. Journal of Paleontology, v. 92, pp. 221-239.

Bhat, M.S., Ray, S., and Datta, P. M., 2018b, A new assemblage of freshwater sharks (Chondrichthyes: elasmobranchii) from the Upper Triassic of India. Geobios, v. 51, pp. 269-283.

Biswas, S.K., 2003, Regional tectonic framework of the PranhitaGodavari basin, India. Journal of Asian Earth Science, v. 21, pp. $1-9$.

Bonaparte, J.F., 1978, El Mesozóico de América de Sur y sus Tetrapodos - The Mesozoic of South America and its tetrapods. Opera Lilloana, v. 26, pp. 1-596.

Bond, D.P.G., and Grasby, S.E., 2017, On the causes of mass extinction. Palaeogeography, Palaeoclimatology, Palaeoecology, v. 478, pp. 3-29.

Brusatte, S.L., Benton, M.J., Ruta, M., and Lloyd, G.T., 2008, Superiority, competition, and opportunism in the evolutionary radiation of dinosaurs. Science, v. 321, pp. 1486-1488.

Buffa, V., Jalil, N.E. and Steyer J.S., 2019, Redescription of Arganasaurus (Metoposaurus) azerouali (Dutuit) comb. nov. from the Upper Triassic of the Argana Basin (Morocco), and the first phylogenetic analysis of the Metoposauridae (Amphibia, Temnospondyli). Papers in Palaeontology, doi: 10.1002/ spp2.1259

Castanhinha, R., Araújo, R., Júnior, L.C., Angielczyk, K.D., Martins, G.G., Martins, R.M. S., Chaouiya, C., Beckmann, F., and Wilde, W., 2013, Bringing dicynodonts back to life: paleobiology and anatomy of a new emydopoid genus from the Upper Permian of Mozambique, Plos One, v. 8, e80974. https://doi.org/10.1371 / journal.pone.0080974

Catuneanu, O.,Wopfner, H., Eriksson, P. G., Cairncross, B., Rubidge, B. S., Smith, R. M. H. and Hancox, P. J., 2005, The Karoo basins of south-central Africa. Journal of African Earth Sciences, v. 43, pp. 211-253.

Chakravorti, S., and Sengupta, D.P., 2019, Taxonomy, morphometry and morphospace of cranial bones of Panthasaurus gen. nov. maleriensis from the Late Triassic of India. Journal of Iberian Geology, v. 45, pp. 317-340.

Chakraborty, C., Mandal, N. and Ghosh, S.K., 2003, Kinematics of the Gondwana basins of peninsular India. Tectonophysics, v. 377, pp. 299-324. 
Chatterjee, S., 1974, A rhynchosaur from the Upper Triassic Maleri Formation of India. Philosophical Transactions of the Royal Society London, v. B267, pp. 209261.

Chatterjee, S., 1978, A primitive parasuchid (phytosaur) reptile from the Upper Triassic Maleri Fornmation of India. Palaeontology, v. 21, pp. 83-127.

Chatterjee, S., 1980, The evolution of rhynchosaurs. Memoires de la Société Géologique de France, v. 139, pp. 57-65.

Chatterjee, S., 1982, A new cynodont reptile from the Triassic of India. Journal of Palaeontology, v. 56, pp. 203-214.

Chatterjee, S., and Mazumdar, P.K., 1987, Tikisuchus romeri, a new rauisuchid reptile from the Late Triassic of India. Journal of Paleontology, v. 61, pp. 787-793.

Chatterjee, S., Scotese, C.R. and Bajpai, S., 2017, The restless Indian plate and its epic voyage from Gondwana to Asia: its tectonic, paleoclimatic, and paleobiogeographic evolution. Geological Society of America Special Paper, v. 529, p. 1-147.

Chen, Z.-Q., and Benton, M. J., 2012, The timing and pattern of biotic recovery following the end-Permian mass extinction. Nature Geoscience, v. 5, pp. 375-383.

Cisneros, J. C., and Abdala, F., 2005, Pareiasaurids from the Rio Do Rasto Formation, southern Brazil: Biostratigraphic implications for Permian faunas of the Parana Basin, Revista Brasileira de Palaeontologia, v. 8, pp. 13-24.

Clark, J., Montellano, M., Hopson, J. A., Hernandez, R. and Fastovsky, D. A., 1994, An Early or Middle Jurassic tetrapod assemblage from the La Boca Formation, northeastern Mexico. In: Fraser, N.C., and Sues H.-D. (Eds.). In The Shadow of the Dinosaurs: Early Mesozoic Tetrapods, Cambridge: Cambridge University Press, pp. 295-302.

Cosgriff, J.W., 1984, The temnospondyl labyrinthodonts from the earliest Triassic. Journal of Vertebrate Paleontology, v. 4, pp. 3046.

Colbert, E.H. and Kitching, J.W., 1977, Triassic cynodont reptiles from Antarctica. American Museum Novitates, no. 2611, pp. 130.

Cotter, G., and De P., 1917, A revised classification of the Gondwana system. Record of the Geological Survey of India, v. 48, pp. 2333.

Crookshank, H., 1936, Geology of the northern slopes of the Satpura between the Morand and Sher rivers. Geological Survey of India, Memoirs, v. 66, pp. 173-381.

Cox, C.B., 1991, The Pangean dicynodont Rechnisaurus and the comparative biostratigraphy of Triassic dicynodont fauna. Palaeontology, v. 34, pp. 767-784.

Cúneo, R., Ramezani, J., Scasso, R., Pol, D., Escapa, I., Zavattieri, A.M., and Browning, S.A., 2013, High precision U-Pb geochronology and a new chronostratigraphy for the Cañadón Asfalto Basin, Chubut, central Patagonia: implications for terrestrial faunal and floral evolution in Jurassic. Gondwana Research, v. 24, pp. 1267-1275.

Damiani, R., Neveling, J., Modesto, S., and Yates, A.M., 2003, Barendskraal, a diverse amniote locality from the Lystrosaurus Assemblage Zone, Early Triassic of South Africa. Palaeontologia Africana, v. 39, pp. 53-62.

Das, D.P., and Gupta, A., 2012, A New Cynodont Record from the Lower Triassic Panchet Formation, Damodar Valley, Journal Geological Society of India, v. 79, pp. 175-180.

Dasgupta, S., and Ghosh, P., 2018, Freshwater carbonates within a Late Triassic siliciclastic fluvial system in a Gondwana rift basin: the Maleri Formation, India. Sedimentary Geology, v. 373, pp. 254-271.

Dasgupta, S., Ghosh, P., and Gierlowski-Kordesch, E.H., 2017, A discontinuous ephemeral stream transporting mud aggregates in a continental rift basin: the Late Triassic Maleri Formation, India. Journal of Sedimentary Research, v. 87, pp. 838-865.

Datta, D., Kumar, N., and Ray, S., 2019a, Taxonomic identification of isolated phytosaur (Diapsida, Archosauria) teeth from the Upper Triassic of India and their significances. Historical Biology, doi: 10.1080/08912963.2019.1613652

Datta, D., Ray, S., and Bandyopadhyay, S., 2019b. Cranial morphology of a new phytosaur (Diapsida, archosauria) from the Upper Triassic of India: implications for phytosaur phylogeny and biostratigraphy. Papers in Palaeontology, doi: 10.1002/spp2.1292.

Datta, P.M., 2004, A suggestion for an early Tuvalian time segment for the Tiki Formation, South Rewa Gondwana basin, India and other correlatable continental sequences. Albertina, v. 30 (suppl), pp. 6-7.

Datta, P.M., 2005, Earliest mammal with transversely expanded upper molar from the Late Triassic (Carnian) Tiki Formation, South Rewa Gondwana basin, India. Journal of Vertebrate Paleontology, v. 25, pp. 200-207.

Datta, P.M., and Das, D.P., 1996, Discovery of the oldest mammal from India. Indian Minerals, v. 50, pp. 217-222.

Datta, P.M., and Ray, S., 2006, Earliest lizards from the Late Triassic (Carnian) of India. Journal of Vertebrate Paleontology, v. 26, pp. 795-800.

Datta, P.M., Das, D.P., and Luo, Z.X., 2004, A Late Triassic dromatheriid (Synapsida: Cynodontia) from India. Annals of the Carnegie Museum, v. 73, pp. 72-84.

Delsate, D., and Ezcurra, M. D., 2014, The first Early Jurassic (late Hettangian) theropod dinosaur remains from the Grand Duchy of Luxembourg. Geologica Belgica, v. 17, pp. 175-181.

Deutsche Stratigraphische Kommisson, 2005, Stratographie von Deutschland, IV - Keuper, Courier Forschungsinstitute Senckenberg, v. 254, pp. 1-296.

Dineen, A.A., Fraiser, M.L., and Sheehan, P.M., 2014, Quantifying functional diversity in pre and post-extinction paleocommunities: A test of ecological restructuring after the end-Permian mass extinction. Earth Science Reviews, v. 136, pp. 339-349.

Dutuit, J.M., 1972, Discovery of an ornithischian dinosaur in the Upper Triassic of the Moroccan western Atlas. Comptes Rendus de l’Académie des Sciences à Paris, Série D, v. 275, pp. 28412844.

Dzik, J., and Sulej, T., 2007, A Review of the early Late Triassic Krasiejow biota from Silesia, Poland. Acta Palaeontologia Polonica, v. 64, pp. 1-27.

Dzik, J., Sulej, T., and NiedŸwiedzki, G., 2007, A dicynodonttheropod association in the latest Triassic of Poland. Acta Palaeontologica Polonica, v. 53, pp. 733-738.

Fedak, T.J., Sues, H.D., and Olsen, P.E., 2015, First record of the tritylodontid cynodont Oligokyphus and cynodont postcranial bones from the McCoy Brook Formation of Nova Scotia, Canada. Canadian Journal of the Earth Science, v. 52, pp. 244-249.

Fortuny, J., Arbez, T., Mujal, E., and Steyer, J.S., 2019, Reappraisal of 'Metoposaurus hoffmani' Dutuit 1978, and description of new temnospondyl specimens from the Middle-Late Triassic of Madagascar (Morondava Basin). Journal of Vertebrate Paleontology, doi: 10.1080/02724634.2019.1576701

Foster, J.R., 2003, Palaeoecological analysis of the vertebrate fauna of the Morrison Formation (Upper Jurassic) Rocky Mountain region, USA. Bulletin of the New Mexico Museum of Natural History and Science, v. 23, pp. 1-95.

Fraser, N.C., 2006, Dawn of the Dinosaurs: Life in the Triassic. Indiana University Press, Bloomington, 328 p.

Fraser, N.C., and Sues, H.D., 2011, The beginning of the 'Age of Dinosaurs': a brief overview of terrestrial biotic changes during the Triassic. Earth and Environmental Science Transactions of 
the Royal Society of Edinburgh, v. 101, pp. 189-200.

Fröbisch, J., 2009, Composition and similarity of global anomodontbearing tetrapod faunas. Earth Science Reviews, v. 95, pp. 119157.

Flynn, J.J., Parrish, J.M., Rakotosamimanana, B., Simpson, W.F., Whatley, R.L., and Wyss, A.R., 1999, A Triassic fauna from Madagascar including earliest dinosaurs. Science, v. 286, pp. 763765.

Galton, P. M., 2019, Earliest record of an ankylosaurian dinosaur (Ornithischia Thyreophora): Dermal armour from Lower Kota Formation (Lower Jurassic) of India. Neues Jahrbuch für Geologie und Paläontologie - Abhandlungen, v. 291 (2), pp. 205-219.

Gandin, A., Tongiorgi, M., Rau, A., and Virgili, C., 1982, Some examples of the Middle-Triassic Marine transgression in SouthWestern Mediterranean Europe. Geologische Rundschau, v. 71, pp. 881-894.

Gradstein, F.M., Ogg, J.G., Schmitz, M.D., and Ogg, G.M., 2012, The Geologic Time Scale 2012. Elsevier Publications, UK, 1144 p.

Gupta, A., 2009, Ichthyofauna of the Lower Triassic Panchet Formation, Damodar valley basin, West Bengal, and its implications. Indian Journal of Geosciences, v. 63, pp. 275-286.

Gupta, A. and Das, D.P. 2011, Report of Lystrosaurus cf. curvatus and $L$. cf. declivis from the Early Triassic Panchet Formation, Damodar Valley, West Bengal, India and its implications. Indian Journal of Geosciences, v. 65, pp. 119-130.

Hallam, A., 1984, Continental humid and arid zones during the Jurassic and Cretaceous. Palaeogeography, Palaeoclimatology, Palaeoecology, v. 47, pp. 195-223.

Hallam, A., 1992, Phanerozoic Sea-level Changes. Columbia University Press, New York, 266 p.

Hammer W.R., and Hickerson W.J., 1996, Implications of an Early Jurassic vertebrate fauna from Antarctica. Museum of Northern Arizona Bulletin, v. 60, pp. 215-218.

Haq, B.U., 2017, Jurassic sea-level variations; a reappraisal. GSA Today, v. 1. doi: 10.1130/GSATG359A

Hautmann, M., 2014, Diversification and diversity partitioning. Paleobiology, v. 40, pp. 162-176.

He, M., Jin, Z., Li, T., Guo, X., and Yang, T., 2014, Stratigraphic framework and microfacies of the Triassic Lower Karamay Formation in districts I, III, NW Junggar, China. Journal of Earth Science, v. 25(6), pp. 1003-1017.

Heckert, A.B., 2004, Late Triassic microvertebrates from the Upper Triassic Chinle Group (Otischalkian-Adamanian: Carnian), southwestern U.S.A. New Mexico Museum of Natural History and Science Bulletin, v. 27, pp. 1-170.

Hofmann, R., Hautmann, M., Wasmer, M., and Bucher, H., 2013, Palaeoecology of the Spathian Virgin Formation (Utah, USA) and its implications for the Early Triassic recovery. Acta Palaeontologica Poland, v. 58, pp.149-173.

Hungerbühler, A., Kutty, T.S., and Chatterjee, S., 2002, New phytosaurs from the Upper Triassic of India. Journal of Vertebrate Paleontology, v. 22(Suppl. 3), pp. 68A.

Hutchinson, M.N., Skinner, A., and Lee, M.S.Y., 2012, Tikiguania and the antiquity of squamate reptiles (lizards and snakes). Biology Letters Royal Society, v. 8, pp. 665-669.

Huxley, T.H., 1865, On a collection of vertebrate fossil from Panchet rocks, Raniganj coalfield. Palaeontologica Indica, v. 4, pp. 2-24.

Irmis, R.B., and Whiteside, J.H., 2011, Delayed recovery of nonmarine tetrapods after the end-Permian mass extinction tracks global carbon cycle. Proceedings of the Royal Society of London, v. B279, https://doi.org/10.1098/rspb.2011.1895.

Irmis, R.B., Martz, J.W., Parker, W.G., and Nesbitt, S.J., 2010, Reevaluating the correlation between Late Triassic terrestrial vertebrate biostratigraphy and the GSSP-defined marine stages. Albertiana, v. 38, pp.40-52.

Irmis, R.B., Mundil, R., Martz, J.W., and Parker, W.G., 2011, Highresolution $\mathrm{U}-\mathrm{Pb}$ ages from the Upper Triassic Chinle Formation (New Mexico, USA) support a diachronous rise of dinosaurs. Earth and Planetary Science Letters, v. 309, pp. 258-267.

Jain, S.L., Robinson, P.L., and Roy Chowdhury, T.K., 1964, A new vertebrate fauna from the Triassic of Deccan, India. Journal of the Geological Society of London, v. 120, pp. 115124.

Kammerer, C.F., Bandyopadhyay, S., and Ray, S., 2016, A new taxon of cistecephalid dicynodont from the upper Permian Kundaram Formation of India. Papers in Palaeontology, v. 2, pp. 569-584.

Keyser, A.W., 1973, A new Triassic vertebrate Fauna from South West Africa. Palaeontolgia Africana, v. 16, pp. 1-15.

King, G.M., 1992, The palaeobiogeography of Permian anomodonts. Terra Nova, v. 4, pp. 633-640.

King, W., 1881, The geology of the Pranhita-Godavari valley. Memoir of Geological Survey of India, v. 18, pp. 151-311.

Kitching, J.W., Collinson, J.W., Elliot, D.H., and Colbert, E.H., 1972, Lystrosaurus Zone (Triassic) Fauna from Antarctica. Science, v. 175, pp. 524-527.

Knoll, F., 2005, The tetrapod fauna of the Upper Elliot and Clarens formations in the main Karoo Basin (South Africa and Lesotho). Bulletin de la Société Géologique de France, v. 176, pp. 81-91.

Kutty, T.S., 1972, Permian reptilian fauna from India. Nature, v. 237, pp. 462-463.

Kutty, T.S., and Sengupta, D.P., 1989, Late Triassic formations of the Pranhita-Godavari valley and their vertebrate faunal sequence - a reappraisal, Indian Journal of Earth Science, v. 16, pp. 189-206.

Kutty, T.S., Jain, S.L., and Roy Chowdhury, T., 1987, Gondwana sequence of the northern Pranhita-Godavari Valley: its stratigraphy and vertebrate faunas. The Palaeobotanist, v. 36, pp. 214-219.

Kutty, T.S., Chatterjee, S., Galton, P.M., and Upchurch, P., 2007, Basal sauropodomorphs (Dinosauria: Saurischia) from the Lower Jurassic of India: their anatomy and relationships. Journal of Paleontology, v. 81, pp. 1218-1240.

Langer, M.C., 2005, Studies on continental Late Triassic tetrapod biochronology. II. The Ischigualastian and a Carnian global correlation. Journal of South American Earth Sciences, v. 19, pp. 219-239.

Langer, M.C., Ribeiro, A.M., Schultz, C.L., and Ferigolo, J., 2007, The continental tetrapod-bearing Triassic of South Brazil. Bulletin of the New Mexico Museum of Natural History and Science, v. 41, pp. 201-218.

Langer, M.C., Da Rosa, Á.A.S., and Montefeltro, F.C., 2017, Supradapedon revisited: geological explorations in the Triassic of southern Tanzania. PeerJ, v. 5, https://doi.org/10.7717/ peerj.4038.

Langer, M.C., Ramezani, J., and Da Rosa, Á.A.S., 2018, U-Pb age constraints on dinosaur rise from south Brazil. Gondwana Research, v. 18, pp. 133-140.

Long, R.A., and Murry, P.A., 1995, Late Triassic (Carnian and Norian) tetrapods from the southwestern United States. Bulletin of the New Mexico Museum of Natural History and Science, v. 4, pp. $1-254$.

Lucas, S.G., 1998, Global Triassic tertapod biostratigraphy and biochronology. Palaeogeography, Palaeoclimatology, Palaeoecology, v. 143, pp. 347-384.

Lucas, S.G., 2009, Global Jurassic tetrapod biochronology. Volumina Jurassica v. 6, pp. 99-108.

Lucas, S.G., 2010, The Triassic timescale based on nonmarine tetrapod biostratigraphy and biochronology, In: Lucas, S.G. (Ed), The Triassic Timescale. Geological Society, London, Special Publications, v. 334, pp. 447-500. 
Lucas, S.G., 2018, Late Triassic terrestrial tetrapods: Biostratigraphy, biochronology and biotic events, 351-405. In: Tanner, L.H. (Ed), The Late Triassic World: Earth in a Time of Transition, Topics in Geobiology. Springer, New York, v. 46, 805 pp.

Lucas, S.G., and Heckert, A.B., 2002, The Hyperodapedon biochron, Late Triassic of Pangaea. Albertiana, v. 27, pp. 30-38.

Lydekker, R., 1885a, The labyrinthodont from the Bijori Group, Memoir Geological Survey of India, Palaeontologia Indica, v.4, p.1-16.

Lydekker, R., 1885b, The Reptilia and Amphibia of the Maleri and Denwa groups. Memoir Geological Survey of India, Palaeontologia Indica. v. 5, pp. 1-38.

Maheswari, H.K., and Kumaran, K.P.N., 1979, Upper Triassic Sporae Dispersae from the Tiki Formation 1: Miospores from the Son River Section between Tharipathar and Ghiyar, South Rewa Gondwana Basin. Paleontographica, v. B71, pp.1-126.

Martínez, R.N., Sereno, P.C., Alcober, O.A., Colombi, C.E, Renne, P.R., Montañez, I.P., and Currie, B.S., 2011, A basal dinosaur from the dawn of the dinosaur era in southwestern Pangaea. Science, v. 331, pp. 206-210.

Martz, J.W., and Parker, W.G., 2017, Revised formulation of the Late Triassic Land Vertebrate "Faunachrons" of western North America: recommendations for codifying nascent systems of vertebrate biochronology, 39-125, In: Zeigler, K.E., and Parker, W.G. (Eds), Terrestrial Depositional Systems: Deciphering Complexities Through Multiple Stratigraphic Methods. Elsevier, 346 pp.

Martz, J.W., Mueller, B., Nesbitt, S.J., Stocker, M.R., Parker, W.G., Atanassov, M., Fraser, N., Weinbaum, J., and Lehane, J., 2013, A taxonomic and biostratigraphic re-evaluation of the Post Quarry vertebrate assemblage from the Cooper Canyon Formation (Dockum Group, Upper Triassic) of southern Garza County, western Texas. Earth and Environmental Science Transactions of the Royal Society of Edinburgh, v. 103, pp. 339-364.

Maulik, P.K., Chakraborty, C., Ghosh, P., and Rudra, D., 2000, Mesoand macro-scale architecture of a Triassic fluvial succession: Denwa Formation, Satpura Gondwana basin, Madhya Pradesh. Journal of the Geological Society of India, v. 56, pp. 489-504.

Mazin, J.M., and King, G.M., 1991, The first dicynodont from the Late Permian of Malagasy. Palaeontology, v. 34, pp. 837-842.

Milner, A.R., Gardiner, B.G., Fraser, N.C., and Taylor, M.A., 1990, Vertebrates from the Middle Triassic Otter Sandstone Formation of Devon. Palaeontology, v. 33, pp. 873-892.

Mukherjee, D., and Ray, S., 2012, Taphonomy of an Upper Triassic vertebrate bonebed-A new rhynchosaur accumulation from India. Palaeogeography, Palaeoclimatology, Palaeoecology, v. 333-334, pp. 75-91.

Mukherjee, D., and Ray, S., 2014, A new Hyperodapedon (Archosauromorpha, Rhynchosauria) from the Upper Triassic of India: implications for rhynchosaur phylogeny. Palaeontology, v. 57, pp. 1241-1276.

Mukherjee, D., Ray, S., and Sengupta, D.P., 2010, Preliminary observations on the bone microstructure, growth patterns, and life habits of some Triassic temnospondyls from India. Journal of Vertebrate Paleontology, v. 30, pp. 78-93.

Mukherjee, D., Sengupta, D.P., and Rakshit, N., 2019, New biological insights into the Middle Triassic capitosaurs from India as deduced from limb bone anatomy and histology. Papers in Palaeontology, doi: 10.1002/spp2.1263

Mukherjee, D., Ray, S., Pal, S., Chandra, S., and Bandyopadhyay, S., 2012, Upper Gondwana succession of the Rewa basin, India: understanding the interrelationship of lithologic and stratigraphic variables. Journal of the Geological Society of India, v. 79, pp. 563-575.
Mukherjee, R.N., and Sengupta D.P., 1998, New capitosaurid amphibians from the middle Triassic Denwa Formation of Satpura Gondwanas, Central India. Alcheringa, v. 22, pp. 317-327.

Mukhopadhyay, G., Mukhopadhyay, S.K., Roychowdhury, M., and Parui, P.K., 2010, Stratigraphic correlation between different Gondwana basins of India. Journal of the Geological Society of India, v. 76, pp. 251-266

Nath, T.T., and Yadagiri, P., 2007, A new mammal-like reptile (Cynodontia) from the Upper Triassic Maleri Formation of Pranhita-Godavari valley, Andhra Pradesh. Journal of the Geological Society of India, v. 69, pp. 57-60.

Nesbitt, S.J., Butler, R.J., Ezcurra, M.D., Barrett, P. M., Stocker, M.R., Angielcyzk, K.D., Smith, R.M.H., Sidor, C.A., NiedŸweidzki, G., Sennikov, A. G., and Charig, A.J., 2017, The earliest bird-line archosaurs and the assembly of the dinosaur body plan. Nature, v. 544, pp. 484-487.

Novas, F.E., Ezcurra, M.D., Chatterjee, S., and Kutty, T.S., 2011, New dinosaur species from the Upper Triassic Upper Maleri and Lower Dharmaram formations of Central India. Transactions of the Royal Society of Edinburgh, v. 101, pp. 333-349.

Ogg, J.G., Ogg, G., and Gradstein, F.M., 2016, A concise geologic time scale 2016. Elsevier, USA, 233 p.

Olsen, P.E., and Galton, P.M., 1977, Triassic-Jurassic tetrapod extinctions: are they real? Science, v. 197, pp. 983-986.

Olsen, P.E., and Sues, H.D., 1986, Correlation of continental Late Triassic and Early Jurassic sediments, and patterns of the TriassicJurassic tetrapod transition. In: K. Padian (Ed.), The Beginning of the Age of Dinosaurs. Cambridge University Press, Cambridge, pp. 321-351.

Olsen, P.E., Kent, D.V., and Whiteside, J.H., 2011, Implications of the Newark Supergroup-based astrochronology and geomagnetic polarity time scale (Newark-APTS) for the tempo and mode of the early diversification of the Dinosauria. Earth and Environmental Science Transactions of the Royal Society of Edinburgh, v. 101, pp. 201-229.

Owen, R., 1855, Description of the cranium of a labyrinthodont reptile, Brachyops laticeps, from Mangli, central India. Quarterly Journal of the Geological Society of London, v. 11, pp. 37-39.

Padian, K., and Sues, H.D., 2015, The age of the transformation: the Triassic period and the rise of today's land vertebrate fauna. In: Dial, K.P., Shubin, N., and Brainerd, E.L. (Eds.), Great Transformations in Vertebrate Evolution. University of Chicago Press, pp. 351-374.

Parmar, V., Prasad, G.V.R. and Kumar, D., 2013, The first multituberculate mammal from India. Naturwissenschaften, v. 100 , pp. 515-523.

Pascoe, E.H., 1975, A Manual of the Geology of India and Burma. Government of India Press, Calcutta, v.II, p. 909-1016.

Pickford, M., 1995, Karoo Supergroup palaeontology of Namibia and brief description of a thecodont from Omingonde. Palaeontologia Africana, v. 32, pp. 51-66.

Pol, D., Garrido, A., and Cerda, I. A., 2011, A new sauropodomorph dinosaur from the Early Jurassic of Patagonia and the origin and evolution of the sauropod-type sacrum. Plos One, v. 26. doi: 10.1371/journal.pone.0014572

Prasad, G.V.R., Singh, K.P.V., Goswami, A., and Sudan, C.S., 2008, Hybodont shark teeth from continental Upper Triassic deposits of India. In: Arratia, G., Schultze, H.P., and Wilson, M.V.H., (Eds), Mesozoic Fishes 4: Homology and Phylogeny. Germany, Verlag Dr. Friedrich Pfeil, p.413-432.

Preto, N., Kustatscher, E., and Wignall, P.B., 2010, Triassic climates - state of the art and perspectives. Palaeogeography, Palaeoclimatology, Palaeoecology, v. 290, pp. 1-10.

Rakshit, N., Bhat, M.S., Ray, S., and Datta, P.M., 2018, First report 
of dinosaurian claws from the Late Triassic of India. Palaeoworld, v. 27, pp. 179-187.

Ray, S., 1999, Permian reptilian fauna from the Kundaram Formation, Pranhita-Godavari valley, India. Journal of African Earth Sciences, v. 29, pp. 211-218.

Ray, S., 2000, Endothiodont dicynodonts from the Late Permian Kundaram Formation of India. Palaeontology, v. 43, pp. 375404.

Ray, S., 2001, Small Permian dicynodonts from India. Paleontological Research, v. 5, pp. 177-191.

Ray, S., 2005, Lystrosaurus (Therapsida, Dicynodontia) from India: Taxonomy, relative growth and cranial dimorphism. Journal of Systematic Palaeontology, v. 3, pp. 203-221.

Ray, S., 2006, Functional and evolutionary aspects of the postcranial anatomy of dicynodonts. Palaeontology, v. 49, pp. 1263-1286.

Ray, S., 2015, A new Late Triassic traversodontid cynodont (Therapsida, Eucynodontia) from India. Journal of Vertebrate Palaeontology, v.35. doi: 10.1080/02724634.2014.930472

Ray, S., and Bandyopadhyay, S., 2003, Late Permian vertebrate community of the Pranhita-Godavari valley, India. Journal of Asian Earth Sciences, v. 21, pp. 643-654.

Ray, S., Bhat, M.S., Mukherjee, D., and Datta, P.M., 2016, Vertebrate fauna from the Late Triassic Tiki Formation of India: new finds and their biostratigraphic implications. The Palaeobotanist, v. 65, pp. 47-59.

Ray, S., Bhat, M.S., and Datta, P.M., 2019, First record of varied archosauriforms from the Upper Triassic of India based on isolated teeth, and their biostratigraphic implications. Historical Biology, doi: 10.1080/08912963.2019.1609957

Remes, K., 2007, A second Gondwanan diplodocid dinosaur from the Upper Jurassic Tendaguru Beds of Tanzania, East Africa. Palaeontology, v. 50, pp. 653-667.

Robinson, P.L., 1970, The Indian Gondwana formations - a review. First International symposium on Gondwana Stratigraphy, IUGS, South America, p. 201-268.

Robinson, P.L., 1973, Palaeoclimatology and continental drift. In: D. H. Tarling and S.K. Runcorn (Eds.). Academic Press, London, pp. 451-476.

Rogers, R.R., Swisher III, C.C., Sereno, P.C., Monetta, A.M., Forster, C.A. and Martínez, R.N., 1993, The Ischigualasto tetrapod assemblage (Late Triassic, Argentina) and 40Ar/39Ar Dating of dinosaur origins. Science, v. 260, pp. 794-797.

Röhl, H.J., Schmid-Rçhl, A., furrer, H., Frimmel, A., Oschmann, W., and Schwark, L., 2001, Microfacies, geochemistry and palaeoecology of the Middle Triassic Grenzbitumenzone from Monte San Giorgo (Canton Ticino, Switzerland). Geol. Insubr., v. 6, pp. 1-13.

Romer, A.S., 1966, Vertebrate Palaeontology. Third edition, Chicago University Press, Chicago.

Roopnarine, P.D., 2018, Ecological persistence, incumbency and reorganization in the Karoo Basin during the Permian-Triassic transition. Earth-Science Reviews, v. 189, pp. 244-263.

Rowe, T.B., 1988, Definition, diagnosis, and origin of Mammalia. Journal of Vertebrate Paleontology, v. 8, pp. 241-264.

RoyChowdhury, T.K., 1965, A new metoposaurid amphibian from the Maleri Formation, India. Philosophical Transactions of the Royal Society London, v. B250, pp. 1-52.

RoyChowdhury, T. K., 1970, Two new dicynodonts from Triassic Yerrapalli Formation of central India. Palaeontology, v. 13 (1), pp. 132-144.

Rubidge, B.S. (Ed), 1995, Biostratigraphy of the Beaufort Group. South African Commission Stratigraphy, Biostratigraphic Series, v.1, p.l”45.

Rubidge, B. S., 2015, Reuniting lost continents - fossil reptiles from the ancient Karoo and their wanderlust. 27th DuToit Memorial Lecture, South African Journal of Geology, v. 108, pp. 135-172.

Rudra, D.K., 1982, Upper Gondwana stratigraphy and sedimentation in the Pranhita-Godavari valley, India. Quarterly Journal of Geological, Mining and Metallurgical Society of India, v. 54, pp. 56-79.

Rudra, D.K., and Maulik, P.K., 1994, Lower Jurassic Kota Limestone of India. In: Gierlowski-Kordesch, E. and Kelts, K. (Eds), Global Geological Record of Lake Basins, Cambridge University Press, Cambridge, v. 1, pp. 185-191.

Sahney, S., and Benton, M.J., 2008, Recovery from the most profound mass extinction of all time. Proceedings of the Royal Society of London, v. B275, pp. 759-765.

Sarkar S., 1988., Petrology of caliche-derived peloidal cacirudite/ calcarenite in the Late Triassic Maleri Formation of the PranhitaGodavari valley, south India. Sedimentary Geology, v. 55, pp. 263-282.

Satsangi, P.P., 1987, The vertebrate faunas of the Permian and Lower Triassic sequence of India. In: Mesozoic Gondwana vertebrates, Geological Survey of India Special Publication, v.11, p.165-178.

Schoch, R.R., Nesbitt, S., Müller, J., Lucas, S.G., and Boy, J.A., 2010, The reptile assemblage from the Moenkopi Formation (Middle Triassic) of New Mexico. Neues Jahrbuch für Geologie und Paläontologie - Abhandlungen, v. 255, pp. 345-369.

Schultz, C.L., Langer, M.C., and Montefeltro, F.C., 2016, A new rhynchosaur from south Brazil (Santa Maria Formation) and rhynchosaur diversity patterns across the Middle-Late Triassic boundary. Paläontologische Zeitschrift, v. 90, pp. 593-609.

Sengupta, D.P., 2002, Indian metoposaurid amphibians revised. Paleontological Research, v. 6, pp. 41-65.

Sengupta, S.M., 1970, Gondwana sedimentation around Bheemaram (Bhimaram), Pranhita-Godavari Valley, India. Journal of Sedimentary Petrology, v. 40, pp. $140-170$.

Sengupta, S., Sengupta, D.P., and Bandyopadhyay, S., 2016, Stratigraphy of the Upper Gondwana formations around Sohagpur: Western part of the Satpura Gondwana Basin, Central India. Journal Geological Society of India, v. 87, pp. 503-519.

Sengupta, S., Ezcurra, M.D., and Bandyopadhyay, S., 2017, A new horned and long-necked herbivorous stem-archosaur from the Middle Triassic of India. Scientific Reports, v. 7 (8366), p. 1-9.

Sennikov, A.G., 1996, Evolution of the Permian and Triassic tetrapod communities of Eastern Europe. Palaeogeography, Palaeoclimatology, Palaeoecology, v. 120 (3-4), pp. 331-351.

Shishkin, M.A., Rubidge, B.S., and Kitching, J.W., 1996, A new lydekkerinid (Amphibia, Temnospondyli) from the Lower Triassic of South Africa: implications for evolution of the early capitosauroid cranial pattern. Philosophical Transactions of the Royal Society of London, v. B351, pp. 1635-1659.

Sidor, C.A., Steyer, J.S., and Hammer, W.R., 2014, A new capitosaurid temnospondyl from the Middle Triassic Upper Fremouw Formation of Antarctica. Journal of Vertebrate Paleontology, v. 34, pp. 539-548.

Smith, R.M.H., 2000, Sedimentology and taphonomy of Late Permian vertebrate fossil localities in southwestern Madagascar. Palaeontologia Africana, v. 36, pp. 25-41.

Smith, R.M.H., and Ward, P.D., 2001, Pattern of vertebrate extinctions across an event bed at the Permian-Triassic boundary in the Karoo Basin of South Africa. Geology, v. 29, pp. 1147-1150.

Smith, R.M.H., Rubidge, B., and van der Wal, M., 2012, Therapsid biodiversity patterns and paleoenvironments of the Karoo Basin, South Africa. In: Chinsamy-Turan, A. (Ed.), Forerunners of Mammals. Indiana University Press, pp. 31-62.

Sookias, R.B., Sullivan, C., Liu, J., and Butler, R.J., 2014, Systematics of putative euparkeriids (Diapsida, Archosauriformes) from the 
Triassic of China. PeerJ, v. 2, doi: 10.7717/peerj.658.

Sues, H.D., and Fraser, N.C., 2010, Triassic Life on Land: The Great Transition. Columbia University Press, New York, 236 pp.

Sues, H.D., Shubin, N.H., and Olsen, P.E., 1994, A new sphenodontian (Lepidosauria: Rhynchocephalia) from the Mccoy Brook Formation (Lower Jurassic) of Nova Scotia, Canada. Journal of Vertebrate Paleontology, v. 14, pp. 327-340.

Tanner, H.T., 2018, The Late Triassic World, Topics in Geobiology 46. Springer, $805 \mathrm{p}$.

Tennant, J.P., Mannion, P.D., and Upchurch, P., 2016, Sea level regulated tetrapod diversity dynamics through the Jurassic/ Cretaceous interval. Nature Communication, v. 712737. doi: 10.1038 /ncomms12737

Tennant, J.P., Mannion, P.D., Upchurch, P., Sutton, M.D., and Price, G.D., 2017, Biotic and environmental dynamics through the Late Jurassic-Early Cretaceous transition: evidence for protracted faunal and ecological turnover. Biological Reviews, v. 92, pp. 776-814.

Tripathi, C., 1962 Rhinesuchus wadiai sp. nov., a new labyrinthodont from Vindhya Pradesh. Records Geological Survey of India, v. 89, pp. 399-406.

Tripathi, C., and Satsangi, P.P., 1963, Lystrosaurus fauna of the Panchet series of the Raniganj coalfield. Memoirs of the Geological Survey of India, New series, v. 37, pp. 1-65.

Tucker, M.E., and Benton, M.J., 1982, Triassic environments, climates and reptile evolution. Palaeogeography, Palaeoclimatology, Palaeoecology, v. 40, pp. 361-379.

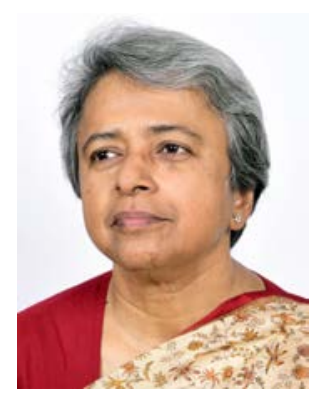

Saswati Bandyopadhyay is the Professor and former Head of the Geological Studies Unit, Indian Statistical Institute, Kolkata. She has specialized mainly in Vertebrate Palaeontology including origin, evolution, functional morphology and systematic study of the Mesozoic reptiles, their taphonomy and bone histology. She has worked on the Indian dinosaurs including the Jurassic sauropod Barapasaurus tagorei and discovered a new horned reptile, Shringasaurus indicus, from the Middle Triassic mudstone of the Satpura Gondwana Basin, India. Besides she has also worked on Indian Gondwana geology including stratigraphy and depositional environment, biochronology and palaeoclimatology.
Twitchett, R.J., 2007, The Lilliput effect in the aftermath of the endPermian extinction event. Palaeogeography, Palaeoclimatology, Palaeoecology, v. 252, pp. 132-144.

Veevers, J.J., and Tewari, R.C., 1995, Gondwana Master Basin of peninsular India between Tethys and interior of the Gondwana provinces of Pangea. Geological Society of America, Memoir, v. 187, pp. 1-72.

Warren, A., 2012, The South African stereospondyl Microposaurus from the Middle Triassic of the Sydney Basin, Australia. Journal of Vertebrate Paleontology, v. 32, pp. 538-544.

Warren, A., Damiani, R., and Sengupta, D.P., 2009, Unique stereospondyl mandibles from the early Triassic Panchet Formation of India and the Arcadia Formation of Australia. Special Papers in Palaeontology, v. 1, pp. 161-173.

Whiteside, J.H., Olsen, P.E., Eglinton, T., Brookfield, M.E., and Sambrotto, R.N., 2010, Compound-specific carbon isotopes from Earth's largest flood basalt eruptions directly linked to the endTriassic mass extinction. Proceedings of the National academy of Sciences of the United States of America, v. 107, pp. 67216725.

Woodward, A.S., 1905, Permo-Carboniferous vertebrates from Kashmir. Palaeontologia lndica New Series, v. 3, pp. 1-13.

Yates, A.M., 2003, A definite prosauropod dinosaur from the Lower Elliot Formation (Norian: Upper Triassic) of South Africa. Palaeontologia Africana, v. 39, pp. 63-68.

Zhang, W., Chen, P. J., and Palmer, A.R., 2003, Biostratigraphy of China. Elsevier Press, 599 p.

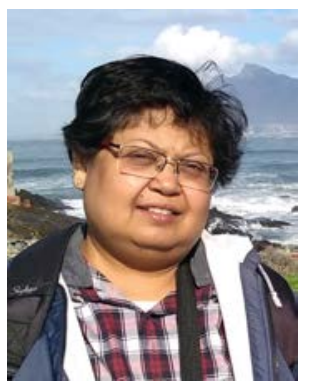

Sanghamitra Ray is a Professor at the Department of Geology and Geophysics, Indian Institute of Technology Kharagpur, India. Her research is focused on various aspects of the Permo-Triassic Gondwana vertebrates, mainly involving deduction of their palaeobiology based on functional morphology and bone histology. During the last few years, she has been actively involved in deciphering the (i), Late Triassic vertebrate faunal assemblages of India and their palaeobiological aspects including mode of life, (ii), various trace fossils and their producers, and (iii) reconstruction of the Triassic palaeo-ecosystem of India. 